\title{
Article \\ Treatment of Winery Wastewater with a Combination of Adsorption and Thermocatalytic Processes
}

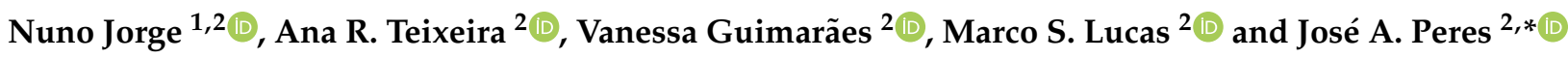 \\ 1 Escuela Internacional de Doctorado (EIDO), Campus da Auga, Campus Universitário de Ourense, \\ Universidade de Vigo, As Lagoas, 32004 Ourense, Spain; njorge@uvigo.es \\ 2 Centro de Química de Vila Real (CQVR), Departamento de Química, Universidade de Trás-os-Montes e Alto \\ Douro (UTAD), Quinta de Prados, 5001-801 Vila Real, Portugal; ritamourateixeira@gmail.com (A.R.T.); \\ guimavs@gmail.com (V.G.); mlucas@utad.pt (M.S.L.) \\ * Correspondence: jperes@utad.pt
}

check for updates

Citation: Jorge, N.; Teixeira, A.R.; Guimarães, V.; Lucas, M.S.; Peres, J.A. Treatment of Winery Wastewater with a Combination of Adsorption and Thermocatalytic Processes. Processes 2022, 10, 75. https:// doi.org/10.3390/pr10010075

Academic Editor: Bipro R. Dhar

Received: 30 November 2021

Accepted: 28 December 2021

Published: 30 December 2021

Publisher's Note: MDPI stays neutral with regard to jurisdictional claims in published maps and institutional affiliations.

Copyright: (C) 2021 by the authors. Licensee MDPI, Basel, Switzerland. This article is an open access article distributed under the terms and conditions of the Creative Commons Attribution (CC BY) license (https:// creativecommons.org/licenses/by/ $4.0 /$ )

\begin{abstract}
The release of winery wastewater (WW) into the environment, without proper treatment, can cause severe problems to freshwater quality and natural fauna and flora. Therefore, in this work a treatment process was studied, combining adsorption and thermocatalytic oxidation processes. In a more specific way, it optimized the combination of activated sodium bentonite (Na-Mt) and potassium persulfate (KPS)/sodium percarbonate (SPC) as oxidant agents. With the combination of best operational conditions of adsorption ([Na-Mt] $=5.0 \mathrm{~g} / \mathrm{L}, \mathrm{pH}=3.0, \mathrm{~V}=500 \mathrm{~mL}$, agitation $350 \mathrm{rpm}, \mathrm{T}=298 \mathrm{~K}, \mathrm{t}=24 \mathrm{~h})$ and thermocatalytic oxidation processes $\left(\mathrm{S}_{2} \mathrm{O}_{8}^{2-} / \mathrm{H}_{2} \mathrm{O}_{2}\right.$ ratio $=1: 0.25$, $\mathrm{S}_{2} \mathrm{O}_{8}^{2-} / \mathrm{H}_{2} \mathrm{O}_{2}$ dosage $=0.1: 0.025(\mathrm{~g} / \mathrm{g}), \mathrm{pH}=7.0, \mathrm{~T}=343 \mathrm{~K}$, agitation $\left.350 \mathrm{rpm}, \mathrm{t}=2 \mathrm{~h}\right)$, a total organic carbon, chemical oxygen demand and total polyphenols removal of 76.7,81.4 and $>99 \%$ was achieved, respectively. Finally, it was evaluated the effect of the treatment processes in the germination index (GI) of different plant seeds. A GI > 80\% was achieved, showing a low phytotoxicity effect of the processes applied in the winery wastewater treatment.
\end{abstract}

Keywords: adsorption process; germination index; phenolic compounds; potassium persulfate; sulfate radicals; sodium percarbonate

\section{Introduction}

Portugal is a Mediterranean wine producer, with an approximated vineyard area of 194,000 ha and a wine production of $6.4 \mathrm{MhL}$ in 2020. It is considered the 11th largest producer and exporter of wine worldwide [1]. To produce wine, wineries generate a significant load of residues. It is estimated that for each liter of wine produced, between 1.3 and $1.5 \mathrm{~kg}$ of wastes are produced. Among these, up to $75 \%$ are WW [2,3]. Most of these wastewaters result from a various number of activities which includes cleaning of tanks, washing of floors and equipment, rinsing of transfer lines, bottling facilities and filtration units $[4,5]$. The release of these winery wastewaters without proper treatment can cause pollution of water, degradation of soil and damage to the vegetation by odors and air emissions [6]. In addition, the discharge of the winery wastewater into the soil without treatment can alter the physicochemical properties of the ground and surface waters, by affecting color, $\mathrm{pH}$ and electrical conductivity from the leaching of organic and inorganic ions [7].

To avoid the negative impact of the winery wastewater in the environment, several treatments have been performed, such as coagulation-flocculation-decantation [8], microalgae [9,10], Fenton and photo-Fenton processes [2,11], sulfate radicals [12] and wet air oxidation [13]. In this work, the application of adsorption with clay was studied as a treatment for winery wastewater. A similar treatment was performed by Jorge et al. [11], who observed a high organic removal from winery wastewater by the bentonite clay. Clays and clay minerals such as montmorillonite, vermiculite, illite, kaolinite and bentonite 
are widely used in petroleum industries, engineering and constructions, environmental remediation, ceramics and refractories, pharmaceuticals and agricultural sectors [14,15].

Bentonite is a 2:1 expandable montmorillonite clay and its unit layer structure consists of one $\mathrm{Al}^{3+}$ octahedral sheets. The modification reactions alter the surface and structural characteristics of clay by replacing the interlayer cations (e.g., $\mathrm{Na}^{+}, \mathrm{K}^{+}, \mathrm{Ca}^{2+}$ ) with specific species or sites [14]. Currently, bentonite is used worldwide to prevent the formation of protein haze in wines before bottling, through a process of adsorption of proteins onto the bentonite clay [16]. However, to our knowledge, the effects of adsorption with bentonite in the phenolic composition and germination index of plants were never studied before in the treatment of winery wastewater, therefore its effects are still unknown.

Sulfate radical-based advanced oxidation processes (SR-AOPs) are another process type that can be applied for winery wastewater treatment. The SR-AOPs have attracted increasing attention due to their advantages, which include: (1) high redox potential (2.5-3.1 V), (2) working under a wide range of $\mathrm{pH}$ [17] and (3) a longer life time (30-40 $\mu \mathrm{s}$ vs. $20 \mathrm{~ns}$ ) than hydroxyl radicals $[18,19]$. The sulfate radicals can be activated by several different techniques such as: (1) alkali activation [20,21], (2) a metal catalyzed process [22-24], (3) heat activation [25,26], (4) radiation activation [27,28], (5) activated carbon [29,30] and (6) $\mathrm{H}_{2} \mathrm{O}_{2}$-based persulfate activation [31]. In this work, the activation of sulfate radicals by addition of potassium persulfate (KPS), hydrogen peroxide $\left(\mathrm{H}_{2} \mathrm{O}_{2}\right)$ and heat was used for the first time in the treatment of winery wastewater. In addition, the application of $\mathrm{H}_{2} \mathrm{O}_{2}$ in solid form as sodium percarbonate (SPC, $\mathrm{Na}_{2} \mathrm{CO}_{3} \bullet 1.5 \mathrm{H}_{2} \mathrm{O}_{2}$ ) was tested for the first time in WW treatment. The SPC has several advantages regarding liquid $\mathrm{H}_{2} \mathrm{O}_{2}$, such as (1) exceptional storage capability, (2) safe to handle, (3) it is a sustained-release oxidizing agent and (4) SPC and its decomposition products, such as carbon dioxide, water and a small amount of sodium carbonate, are non-toxic to microorganisms in groundwater [32].

The aim of this work is (1) to evaluate the performance of activated sodium bentonite in the adsorption process for the treatment of WW, (2) to study and optimize the thermocatalytic oxidation for the treatment of WW, (3) to evaluate the effect of combined treatment adsorption-thermocatalytic oxidation processes in the germination index of plant seeds and removal of phenolic compounds.

\section{Materials and Methods}

\subsection{Reagents and Winery Wastewater Sampling}

Activated sodium Bentonite (Na-Mt) was purchased by Angelo Coimbra \& Ca., Lda (Maia, Portugal), sodium percarbonate ( $\mathrm{SPC}, \mathrm{Na}_{2} \mathrm{CO}_{3} \bullet 1.5 \mathrm{H}_{2} \mathrm{O}_{2}$ ) by Alfa Aesar (Massachusetts, EUA) and persulfate or potassium peroxydisulfate (KPS, $\mathrm{K}_{2} \mathrm{~S}_{2} \mathrm{O}_{8}$ ), by Scharlau (Sentmenat, Barcelona, Spain). $\mathrm{NaOH}$ and $\mathrm{H}_{2} \mathrm{SO}_{4}(95 \%)$ were acquired by Analar Normapur (Vila Nova de Gaia, Portugal). Deionized water was used to prepare the respective solutions. The WW was collected from a private Portuguese cellar unity located in the Douro region (Northeast of Portugal). The WW samples were stored at $-40{ }^{\circ} \mathrm{C}$, and the work was performed at the University of Trás-os-Montes and Alto Douro, located in Vila Real, Portugal, latitude $41^{\circ} 17^{\prime} 9.18^{\prime \prime} \mathrm{N}$ and longitude $7^{\circ} 44^{\prime} 21.45^{\prime \prime} \mathrm{W}$.

\subsection{Analytical Technics}

Different physical-chemical parameters were measured in order to characterize the WW, including the chemical oxygen demand (COD), the biological oxygen demand $\left(\mathrm{BOD}_{5}\right)$, the total organic carbon (TOC) and the total polyphenols (mg gallic acid/L). The main chemical parameters measured are shown in Table 1 . The COD and $\mathrm{BOD}_{5}$ were determined according to Standard Methods (5220D; 5210D, respectively) [33]. COD analysis was carried out in a COD reactor from HACH Co. (Loveland, $\mathrm{CO}, \mathrm{USA}$ ) and a HACH DR 2400 spectrophotometer (Loveland, CO, USA) was used for colorimetric measurement. Biochemical oxygen demand $\left(\mathrm{BOD}_{5}\right)$ was determined using a respirometric OxiTop ${ }^{\circledR}$ IS 12 system (WTW, Yellow Springs, OH, USA). The $\mathrm{pH}$ was measured by a $3510 \mathrm{pH}$ meter (Jenway, Cole-Parmer, UK). The TOC content (mg C/L) was measured by a Shimadzu 
TOC-L CSH analyzer (Shimadzu, Kyoto, Japan). Total polyphenols content was determined following the Folin-Ciocalteau method [34]. Hydrogen peroxide concentration was followed using titanium (IV) oxysulfate (DIN $38402 \mathrm{H} 15$ method) at $410 \mathrm{~nm}$, by a HACH DR 2400 spectrophotometer (Loveland, CO, USA).

Phytotoxicity tests were performed, by germination of onion, cucumber, lettuce and corn seeds (standard species recommended by the US Environmental Protection Agency, the US Food and Drug Administration and the Organization for Economic Cooperation and Development [35]) and determined by Equation (1) in accordance to Varnero et al. [36] and Tiquia and Tam [37], as follows:

$$
\mathrm{GI}(\%)=\frac{\overline{\mathrm{N}}_{\mathrm{SG}, \mathrm{T}}}{\overline{\mathrm{N}}_{\mathrm{SG}, \mathrm{B}}} \times \frac{\overline{\mathrm{L}}_{\mathrm{R}, \mathrm{T}}}{\overline{\mathrm{L}}_{\mathrm{R}, \mathrm{B}}} \times 100
$$

where GI is the germination index, $\overline{\mathrm{N}}_{\mathrm{SG}, \mathrm{T}}$ is the arithmetic mean of the number of germinated seeds in each extract (wastewater), $\bar{N}_{S G, B}$ is the arithmetic mean of the number of germinated seeds on standard solution (distilled water), $\overline{\mathrm{L}}_{\mathrm{R}, \mathrm{T}}$ is the mean root length in each extract (wastewater) and $\bar{L}_{\mathrm{R}, \mathrm{B}}$ is the mean root length in control (distilled water).

Table 1. Physical-chemical characterization of winery wastewater [38].

\begin{tabular}{cc}
\hline Parameter & Value \\
\hline $\mathrm{pH}$ & 4.0 \\
Conductivity $(\mu \mathrm{S} / \mathrm{cm})$ & 385 \\
Turbidity $(\mathrm{NTU})$ & 1205 \\
Total Suspended Solids $(\mathrm{mg} / \mathrm{L})$ & 3910 \\
Chemical Oxygen Demand $\left(\mathrm{mg} \mathrm{O}_{2} / \mathrm{L}\right)$ & 9870 \\
Biochemical Oxygen Demand $\left(\mathrm{mg} \mathrm{O}_{2} / \mathrm{L}\right)$ & 1250 \\
Total Organic Carbon $\left(\mathrm{mg} \mathrm{C}_{\mathrm{L}}\right)$ & 1497 \\
Total Polyphenols $(\mathrm{mg}$ gallic acid/L) & 87 \\
Ferrous Iron $(\mathrm{mg} \mathrm{Fe} / \mathrm{L})^{\text {Biodegradability Index-BOD } / \mathrm{COD}}$ & 0.05 \\
\hline
\end{tabular}

\subsection{Phenolic and Chromatic (CIELab) Characterization}

Color intensity (CI) and Hue were measured as described by the OIV method [39]; total polyphenol index (TPI) was measured using the Curvelo-Garcia method [40]; total phenols, non-flavonoids and flavonoids were determined according to Kramling and Singleton [41]. Total anthocyanins (C) were analyzed by $\mathrm{SO}_{2}$ bleaching method, as reported by Ribéreau-Gayon et al. [42]; colored anthocyanins (CA), total pigments (TP) and polymeric pigments (PP) were determined by the method described by Somers and Evans [43] and total tannins were determined by the leucoanthocyanin (LA) method [44]. All samples were analyzed by a GENESYS ${ }^{\mathrm{TM}} 10$ Series Spectrophotometer (Thermo Fisher Scientific, Waltham, Massachusetts, USA). A Shimadzu UV-2101 spectrophotometer (Shimadzu, Kyoto, Japan) was used to record the absorption spectra of the WW samples, with a scan from a range between 380 and $770 \mathrm{~nm}$, with $5 \mathrm{~nm}$ distance, using $1 \mathrm{~cm}$ path length quartz cells. Data were collected to determine a measure of $L$ (lightness), $a$ (redness) and $b$ (yellowness) coordinates using the CIELab 1976 method. This allows reliable quantification of the overall color difference of a sample when compared to a reference sample (Blanc). Color differences can be distinguished by the human eye when the difference between $\Delta E_{\mathrm{ab}}$ values are greater than two units, in accordance to Spagna et al. [45]. All analyses were performed in duplicate. Table 2 resumes the formulas used in this work. 
Table 2. Equations for phenolic composition and chromatic (CIELab) determination [38].

\begin{tabular}{|c|c|c|}
\hline Equations & Parameters & References \\
\hline Color intensity $(\mathrm{CI})$ & $\mathrm{A}_{420 \_ \text {absorbance at } 420 \mathrm{~nm}}$ & OIV, [39] \\
\hline $\mathrm{CI}=\mathrm{A}_{420}+\mathrm{A}_{520}+\mathrm{A}_{620}$ & $\mathrm{~A}_{520}$-absorbance at $520 \mathrm{~nm}$ & \\
\hline Hue & $\mathrm{A}_{620}$-absorbance at $620 \mathrm{~nm}$ & OIV, [39] \\
\hline Hue $=\frac{\mathrm{A}_{420}}{\mathrm{~A}_{50}}$ & $\mathrm{~A}_{280}$-absorbance at $280 \mathrm{~nm}$ & \\
\hline Total polyphenol index (TPI) & DF-dilution factor & Curvelo-Garcia, [40] \\
\hline \multicolumn{3}{|l|}{$\mathrm{TPI}=\mathrm{A}_{280} \times \mathrm{DF}$} \\
\hline Total phenols & & Kramling and Singleton, [41] \\
\hline \multicolumn{2}{|c|}{ Total phenols $(\mathrm{mg}$ gallic acid $/ \mathrm{L})=\frac{\mathrm{A}_{280}^{\mathrm{IPT}}+0.0243}{0.0326} \times \mathrm{DF}$} & Kramling and Singleton, [41] \\
\hline $\begin{array}{c}\text { Non-flavonoids (mg gallic acid } / \mathrm{L})=\frac{\mathrm{A}_{280}^{\mathrm{NF}}+0}{0.03} \\
\text { Flavonoids } \\
\begin{array}{c}\text { Flavonoids (mg gallic acid } / \mathrm{L})=\mathrm{To} \\
\text { phenols-Non-flavonoids }\end{array}\end{array}$ & & Kramling and Singleton, [41] \\
\hline Total anthocyanins (C) & $\mathrm{A}_{1 \_ \text {absorbance at } 520 \mathrm{~nm}}$ & \multirow[t]{2}{*}{ Ribéreau-Gayon et al. [42] } \\
\hline $\mathrm{C}(\mathrm{mg} / \mathrm{L})=875 \times\left(\mathrm{A}_{1}-\mathrm{A}_{2}\right)$ & $\mathrm{A}_{2}$ _absorbance at $520 \mathrm{~nm}$ & \\
\hline Colored anthocyanins (CA) & & \multirow[t]{2}{*}{ Somers and Evans [43] } \\
\hline $\mathrm{CA}(\mathrm{mg} / \mathrm{L})=\left(\mathrm{A}_{520}^{\text {no bisulfite }} \times 10\right)-\left(\mathrm{A}_{520}^{\text {bisulf }}\right.$ & & \\
\hline Total pigments (TP) & & \multirow[t]{2}{*}{ Somers and Evans [43] } \\
\hline $\mathrm{TP}(\mathrm{mg} / \mathrm{L})=\mathrm{A}_{520}^{\mathrm{HCl}} \times 10$ & & \\
\hline Polymeric pigments (PP) & & \multirow[t]{2}{*}{ Somers and Evans [43] } \\
\hline $\mathrm{PP}(\mathrm{mg} / \mathrm{L})=\mathrm{A}_{520}^{\text {bisulfite }} \times 10$ & & \\
\hline Total tannins (L.A.) & & Ribéreau-Gayon and Stonestreet [44] \\
\hline L.A. $(g / L)=19.33 \times\left(D_{2}-D_{1}\right)$ & $\mathrm{D}_{1} / \mathrm{D}_{2}$ absorbance at $550 \mathrm{~nm}$ & \\
\hline CIELab & $L$-lightness & Schanda [46] \\
\hline$\Delta L=L_{1}-L_{0}$ & $A$-redness & \\
\hline$\Delta a=a_{1}-a_{0}$ & $B$-yellowness & \\
\hline $\begin{array}{c}\Delta b=b_{1}-b_{0} \\
\Delta E_{\mathrm{ab}}=\left[\Delta(L)^{2}+\Delta(a)^{2}+\Delta(b)^{2}\right]\end{array}$ & & \\
\hline
\end{tabular}

\subsection{Characterization of Activated Sodium Bentonite}

The structural composition of bentonite was studied by Fourier-transform infrared spectroscopy (FTIR) spectra, which was obtained by mixing $2 \mathrm{mg}$ of Na-Mt powder with $200 \mathrm{mg}$ potassium bromide (KBr). The powder was introduced into molds and pressed at 10 ton $/ \mathrm{cm}^{-2}$ to obtain the transparent pellets, which were analyzed by a Bruker Tensor 27 spectrometer, and the infrared spectra in transmission mode were recorded in the $4000-400 \mathrm{~cm}^{-1}$ frequency region. The microstructural characterization of the Na-Mt was performed by scanning electron microscope (FEI QUANTA 400 SEM/ESEM, Fei Quanta, Hillsboro, WA, USA) and the chemical composition of the bentonite was estimated (Table 3) using the energy dispersive X-ray spectroscopy (EDS/EDAX, PAN'alytical X'Pert PRO, Davis, CA, USA).

Table 3. Chemical composition of activated sodium bentonite (Na-Mt), by EDS/EDAX [38].

\begin{tabular}{cc}
\hline Element & Mass Concentration (wt (\%)) \\
\hline$\% S i$ & 69.49 \\
$\% \mathrm{Al}$ & 17.67 \\
$\% \mathrm{Fe}$ & 2.95 \\
$\% \mathrm{Mg}$ & 2.73 \\
$\% \mathrm{Ca}$ & 2.00 \\
$\% \mathrm{Na}$ & 2.76 \\
$\% \mathrm{~K}$ & 1.37 \\
$\% \mathrm{~S}$ & 1.03 \\
\hline
\end{tabular}


The textural parameters of the bentonite were obtained from $\mathrm{N}_{2}$ adsorption-desorption isotherms at $77 \mathrm{~K}$ using a Micromeritics ASAP 2020 apparatus (TriStar II Plus, Micromeritics Instrument Corporation, Norcross, GA, USA). The bentonite sample was degassed at $150{ }^{\circ} \mathrm{C}$ up to $10^{-4}$ Torr before analysis. The specific surface area (SBET) was then measured by applying Gurevitsch's rule at a relative pressure $\mathrm{p} / \mathrm{p}_{0}=0.30$ and according to the Brunauer, Emmet, Teller (BET) method from the linear part of the nitrogen adsorption isotherms. Different pore volumes were determined by the Barrett, Joyner, Halenda model (BJH model).

From FTIR analysis (Figure 1) [38], Na-Mt exhibits the stretching vibration of structural $\mathrm{O}-\mathrm{H}$ groups at $3645 \mathrm{~cm}^{-1}$, structural Si-O groups at 1103, 999 and $789 \mathrm{~cm}^{-1}$, structural $\mathrm{Al}-\mathrm{O}-\mathrm{Al}-\mathrm{OH}$ groups at $902 \mathrm{~cm}^{-1}$, structural $\mathrm{Al}-\mathrm{O}-\mathrm{Fe}-\mathrm{OH}$ groups at $883 \mathrm{~cm}^{-1}$, the free and interlayer water in bond stretching vibration at $3396 \mathrm{~cm}^{-1}$ and adsorbed water yielded bending at $1643 \mathrm{~cm}^{-1}[47-50]$.

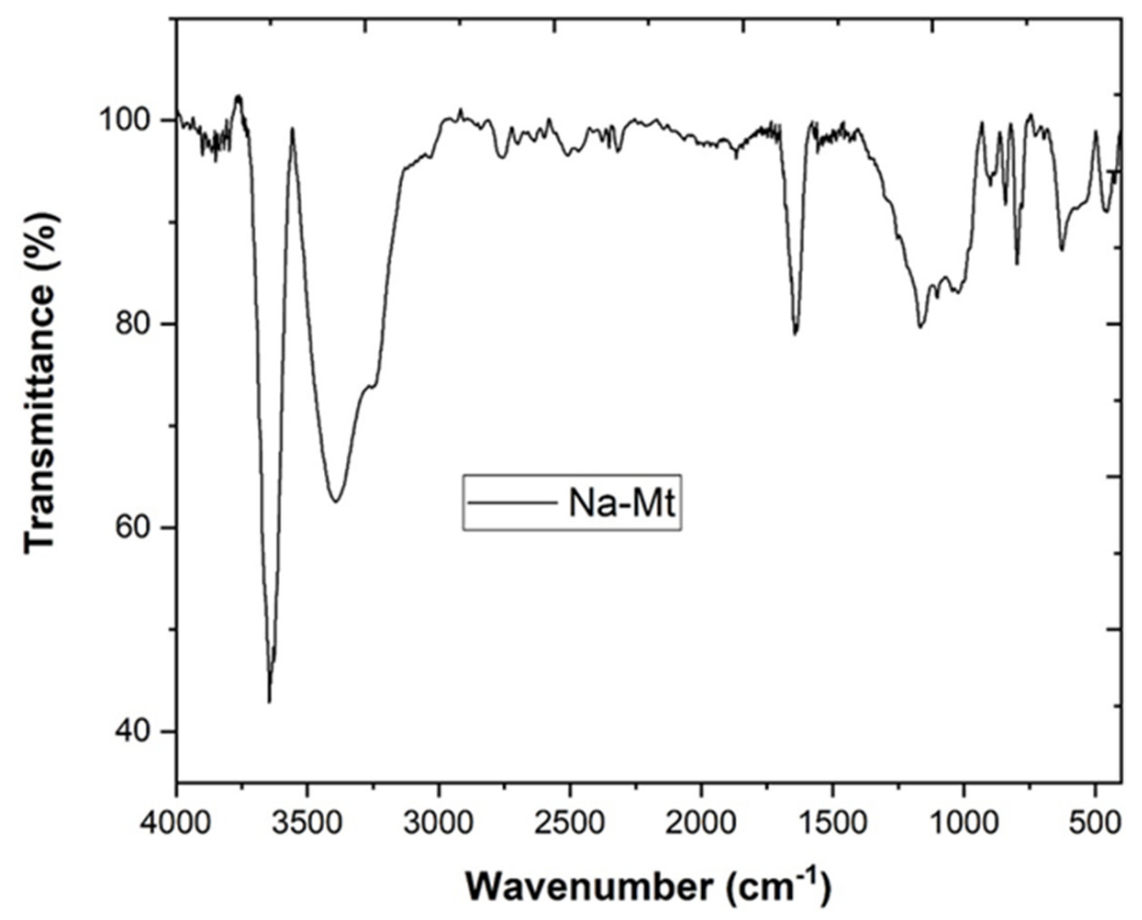

Figure 1. Fourier-transform infrared spectroscopy (FTIR) spectra of Na-Mt.

The results obtained by BET analysis showed that bentonite exhibited a mesoporous structure with a specific surface area of $8.8 \mathrm{~m}^{2} / \mathrm{g}$, a total pore volume of $0.045 \mathrm{~cm}^{3} / \mathrm{g}$ and a particle size of $4.0 \mathrm{~nm}$. The respective isotherms can be classified as type II, where unrestricted monolayer-multilayer adsorption occurs, and the behavior of the hysteresis loops can be associated with type $\mathrm{H} 3$, which usually corresponds to aggregates of plate-like particles forming slit-like pores [51], which is in agreement with these material structures.

\subsection{Adsorption Experimental Setup}

The adsorption of organic matter from WW on Na-Mt material was studied in detail (Figure 2), in order to predict the amount of organic carbon that was removed through adsorption. The adsorption process was optimized as follows:

1. Variation of $\mathrm{pH}(2.0-11)$ under the following operational conditions: $[\mathrm{Na}-\mathrm{Mt}]=3.0 \mathrm{~g} / \mathrm{L}$, $\mathrm{V}=500 \mathrm{~mL}$, agitation $350 \mathrm{rpm}, \mathrm{T}=298 \mathrm{~K}, \mathrm{t}=24 \mathrm{~h}$;

2. Variation of Na-Mt dosage $(0.5-10 \mathrm{~g} / \mathrm{L})$ under the following operational conditions: $\mathrm{pH}=3.0, \mathrm{~V}=500 \mathrm{~mL}$, agitation $350 \mathrm{rpm}, \mathrm{T}=298 \mathrm{~K}, \mathrm{t}=24 \mathrm{~h}$.

After $24 \mathrm{~h}$, samples were centrifuged and filtrated for analysis. 


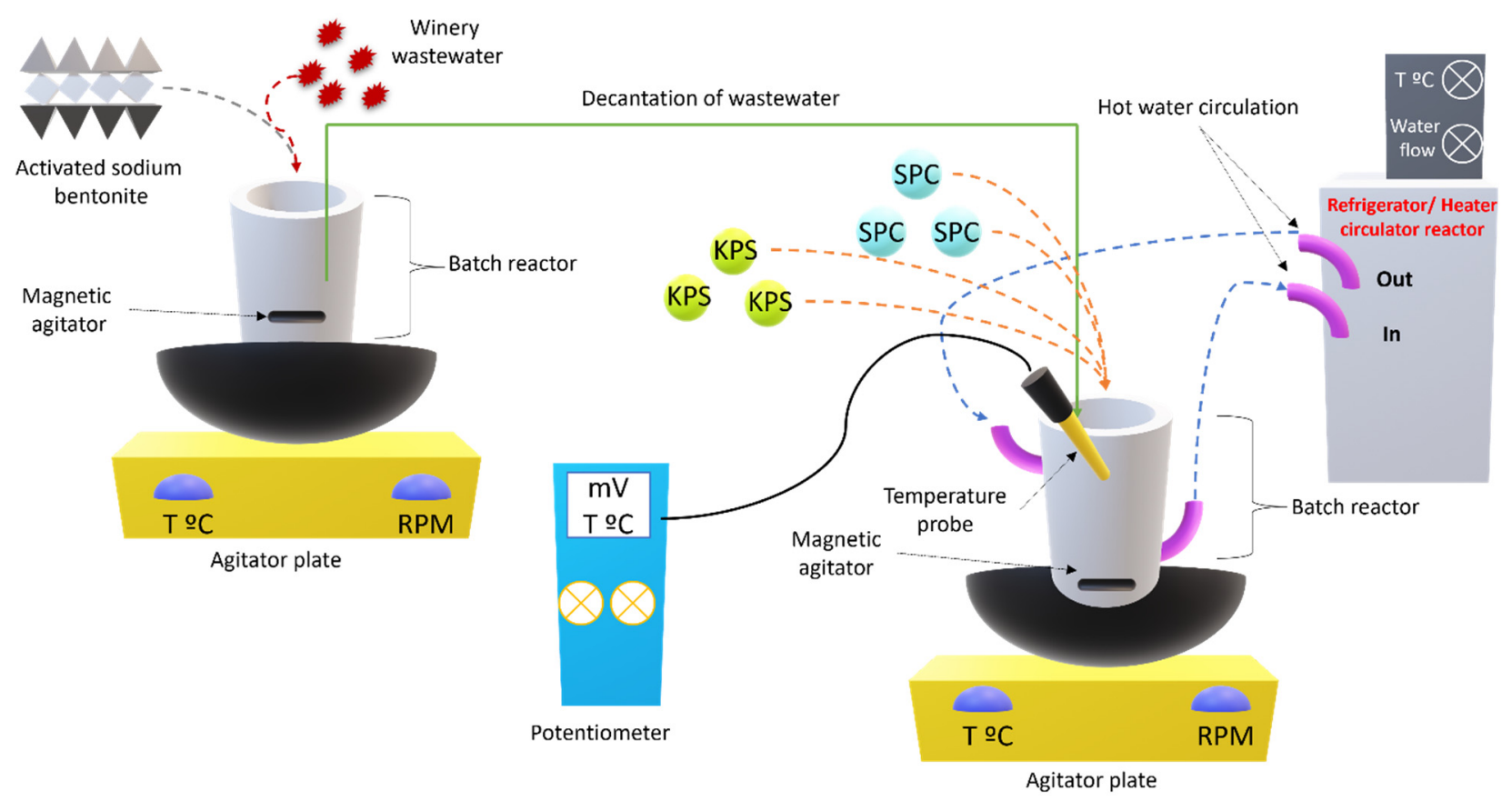

\section{Adsorption process Thermocatalytic oxidation}

Figure 2. Illustration of the adsorption and thermocatalytic oxidation processes.

\subsection{Thermocatalytic Experimental Setup}

The thermocatalytic oxidation process (Figure 2) was carried out by a refrigerator/heater circulator reactor (Julabo F25, Seelbach, Germany). The heater is equipped with a power of $2.2 \mathrm{~kW}$ and the refrigerator as a power of $0.170 \mathrm{~kW}$. To achieve the maximum removal efficiency, thermocatalytic experiments were carried as follows:

1. Variation of $\mathrm{S}_{2} \mathrm{O}_{8}^{2-} / \mathrm{H}_{2} \mathrm{O}_{2}$ ratio $(1: 0 ; 1: 0.25 ; 1: 0.50 ; 1: 0.75 ; 1: 1 ; 1: 1.5)$ under the following operational conditions: $\left[\mathrm{S}_{2} \mathrm{O}_{8}^{2-}\right]=1.0 \mathrm{~g} / \mathrm{L}, \mathrm{pH}=11.0, \mathrm{~T}=333 \mathrm{~K}$, agitation $350 \mathrm{rpm}$, $\mathrm{t}=2 \mathrm{~h}$;

2. Variation of $\mathrm{S}_{2} \mathrm{O}_{8}^{2-} / \mathrm{H}_{2} \mathrm{O}_{2}$ dosage $(0.1: 0.025 ; 0.5: 0.125 ; 1: 0.25 ; 1.5: 0.375 ; 2: 0.5)$ under the following operational conditions: $\mathrm{S}_{2} \mathrm{O}_{8}^{2-} / \mathrm{H}_{2} \mathrm{O}_{2}$ ratio $=1: 0.25, \mathrm{pH}=11.0, \mathrm{~T}=333 \mathrm{~K}$, agitation $350 \mathrm{rpm}, \mathrm{t}=2 \mathrm{~h}$;

3. Variation of $\mathrm{pH}(3.0,5.0,7.0,9.0,11)$ under the following operational conditions: $\mathrm{S}_{2} \mathrm{O}_{8}^{2-} / \mathrm{H}_{2} \mathrm{O}_{2}$ ratio $=1: 0.25, \mathrm{~S}_{2} \mathrm{O}_{8}^{2-} / \mathrm{H}_{2} \mathrm{O}_{2}$ dosage $=0.1: 0.025(\mathrm{~g} / \mathrm{g}), \mathrm{T}=333 \mathrm{~K}$, agitation $350 \mathrm{rpm}, \mathrm{t}=2 \mathrm{~h}$;

4. Variation of temperature $(303,313,323,333$ and $343 \mathrm{~K})$ under the following operational conditions: $\mathrm{S}_{2} \mathrm{O}_{8}^{2-} / \mathrm{H}_{2} \mathrm{O}_{2}$ ratio $=1: 0.25, \mathrm{~S}_{2} \mathrm{O}_{8}^{2-} / \mathrm{H}_{2} \mathrm{O}_{2}$ dosage $=0.1: 0.025(\mathrm{~g} / \mathrm{g})$, $\mathrm{pH}=7.0$, agitation $350 \mathrm{rpm}, \mathrm{t}=2 \mathrm{~h}$.

After $2 \mathrm{~h}$, samples were centrifuged and filtrated for analysis. The percentage of contaminant removed through adsorption and thermocatalytic oxidation was calculated in accordance to Equation (2) [52], as follows:

$$
\mathrm{X}_{\mathrm{i}}=\frac{\mathrm{C}_{0}-\mathrm{C}_{\mathrm{f}}}{\mathrm{C}_{0}} \times 100
$$

where $\left(\mathrm{X}_{\mathrm{i}}\right)$ of water contamination represents turbidity, TSS, COD and total polyphenol; $\mathrm{C}_{0}$ and $C_{f}$ are the initial and final concentrations, respectively. 


\subsection{Statistical Analysis}

All experiments were performed at least in duplicate and the observed standard deviation was always less than $5 \%$ of the reported value. Statistical analysis was performed using one-way analysis of variance (ANOVA) and differences were considered significant when $p<0.05$. Average values were compared using Tukey's test. The statistical analyses were performed using OriginLab 2019 software (Northampton, MA, USA). The data are presented as mean and standard error (mean $\pm \mathrm{SE}$ ).

\section{Results and Discussion}

\subsection{Adsorption Experiments with Bentonite}

\subsubsection{Effect of $\mathrm{pH}$}

The ability of activated sodium Bentonite (Na-Mt) to adsorb and remove the organic content from the WW was accessed at different $\mathrm{pH}$ conditions (2.0-11.0), under the following operational conditions: [Na-Mt] $=3.0 \mathrm{~g} / \mathrm{L}, \mathrm{V}=500 \mathrm{~mL}$, agitation $350 \mathrm{rpm}, \mathrm{T}=298 \mathrm{~K}$, $\mathrm{t}=24 \mathrm{~h}$. It is known that the variable charge of montmorillonite is significantly affected by $\mathrm{pH}$, due to the ionization of its external hydroxyl groups [53]. At $\mathrm{pH}$ lower than $\mathrm{pH}_{\mathrm{pzc}}$ $(\mathrm{pH}$ at the point of zero charge), the clay exhibits anionic exchange capacity, while at $\mathrm{pH}$ greater than $\mathrm{pH}_{\mathrm{pzc}}$, the clay displays high cation-exchange capacity. In the case of bentonite, it renders negative charge on its surface due to its isomorphous substitution of $\mathrm{Al}^{3+}$ for $\mathrm{Si}^{4+}$ in tetrahedral layer and $\mathrm{Mg}^{2+}$ for $\mathrm{Al}^{3+}$ in octahedral sheet and therefore can attract positively charged pollutants $[14,54]$. However, as observed by several authors $[55,56]$, the mechanism of adsorption on clays is mainly controlled by the adsorption on its interlayer region, since about $85-90 \%$ of the available sites for adsorption are located on its internal surface. In this way, the permanent negative charge of montmorillonite is compensated by the cation exchange process, where the initial $\mathrm{Na}^{+}$ions may be replaced by positively charged species. Therefore, the contaminant uptake will significantly depend on its charge at given $\mathrm{pH}$ [53].

The results in Figure 3, showed a significant increase in TOC removal from $\mathrm{pH} 2.0$ to 3.0 (48.0 and $54.9 \%$, respectively), decreasing as the $\mathrm{pH}$ increased to 5.0, 7.0, 9.0 and $11.0(52.2,50.2,49.9$ and $41.2 \%$, respectively). In this work, the higher adsorption capacity obtained at $\mathrm{pH}$ 3.0, was probably related with the concentration of amphoteric flavylium species present in the WW, making them potentially treated by adsorption. Thus, at $\mathrm{pH} 3.0$ these species acquired positive charge and exchanged the $\mathrm{Na}^{+}$ions initially adsorbed on the interlayer region [53]. Increasing the $\mathrm{pH}>3.0$, the isoelectric point of bentonite was reached $(\mathrm{pH}=7)$ [57], decreasing the bentonite adsorption capacity. In a study performed by Sharma et al. [58] it was observed that the adsorption capacity of methyl blue, anionic dye, onto the clay was decreased with the increase in initial $\mathrm{pH}$ of the suspension to alkaline $\mathrm{pH}$. Therefore, considering these results, $\mathrm{pH} 3.0$ was selected as the best $\mathrm{pH}$ for the adsorption process.

\subsubsection{Effect of Na-Mt Dosage}

In the previous section, it was observed that the $\mathrm{pH}$ had a significant effect in the adsorption process of WW by Na-Mt. However, the effect of Na-Mt dosage in adsorption process is still unknown; therefore, in this section it was varied the Na-Mt dosage $(0.5-10.0 \mathrm{~g} / \mathrm{L})$ under the following operational conditions: $\mathrm{pH}=3.0, \mathrm{~V}=500 \mathrm{~mL}$, agitation $350 \mathrm{rpm}, \mathrm{T}=298 \mathrm{~K}, \mathrm{t}=24 \mathrm{~h}$.

In Figure 4, it was observed an increase in TOC removal, with the increase in Na-Mt dosage from 0.5 to $5.0 \mathrm{~g} / \mathrm{L}$ ( 39.5 to $61.1 \%$, respectively). From 5.0 to $10.0 \mathrm{~g} / \mathrm{L} \mathrm{Na-Mt}$, a small decrease in TOC removal was observed from 61.1 to $56.3 \%$, respectively. Therefore, the application of Na-Mt dosages higher than $5.0 \mathrm{~g} / \mathrm{L}$ were not considered viable, due to the low TOC removal results, as well as from an economic point of view, due to high Na-Mt application. In the work of Guimarães et al. [53] and Jorge et al. [11] it was also observed that application of clay concentrations higher than $3.0 \mathrm{~g} / \mathrm{L}$ were not suitable for adsorption process of organic matter of WW. 


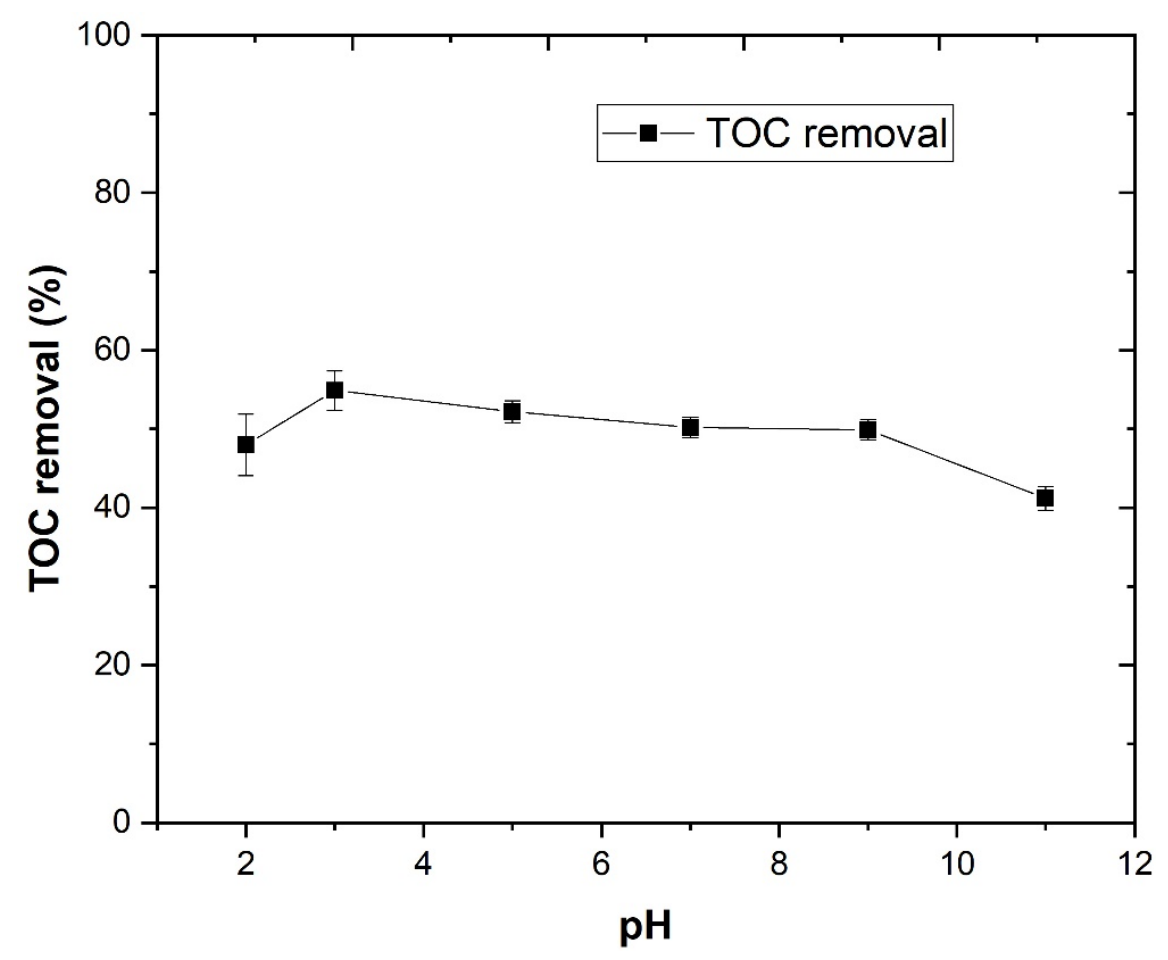

Figure 3. Effect of $\mathrm{pH}(2.0-11.0)$ in WW organic matter adsorption onto Na-Mt, under the following operational conditions: [Na-Mt] $=3.0 \mathrm{~g} / \mathrm{L}, \mathrm{V}=500 \mathrm{~mL}$, agitation $350 \mathrm{rpm}, \mathrm{T}=298 \mathrm{~K}, \mathrm{t}=24 \mathrm{~h}$.

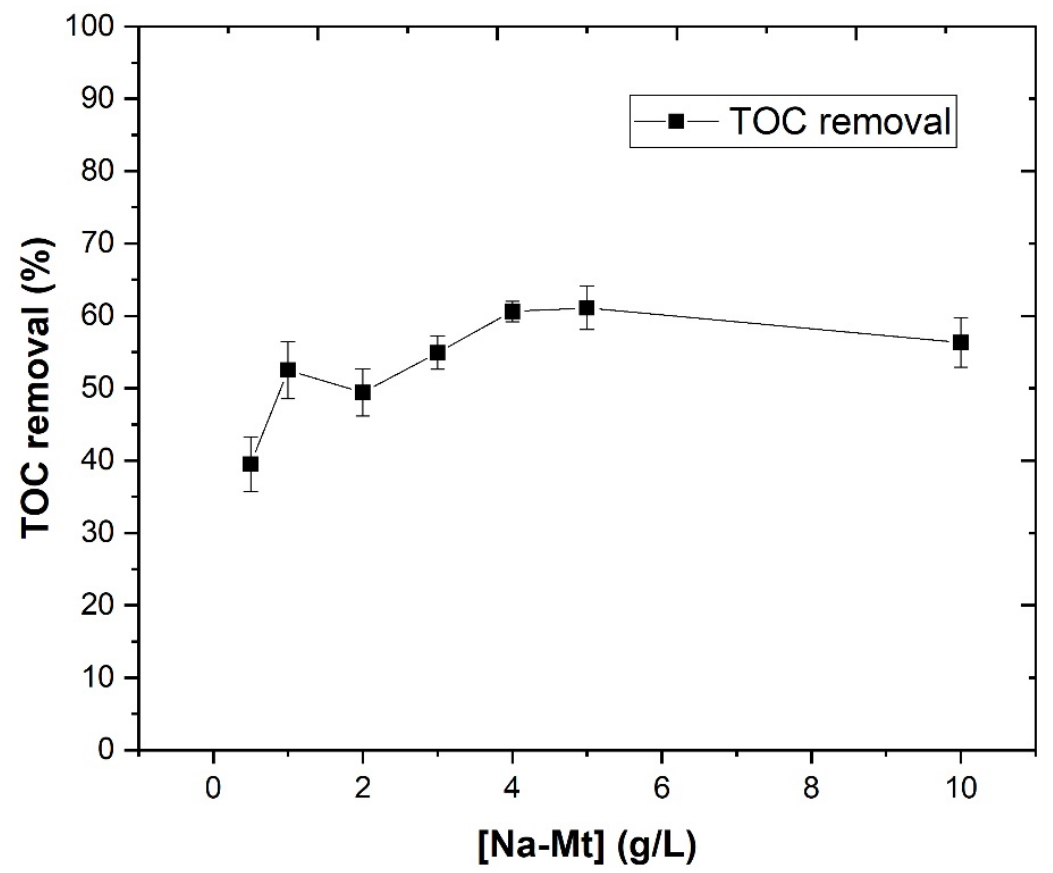

Figure 4. Effect of Na-Mt dosage variation (0.5-10.0 g/L) in adsorption of organic matter from WW onto Na-Mt, under the following operational conditions: $\mathrm{pH}=3.0, \mathrm{~V}=500 \mathrm{~mL}$, agitation $350 \mathrm{rpm}$, $\mathrm{T}=298 \mathrm{~K}, \mathrm{t}=24 \mathrm{~h}$.

Therefore, based on these results, the Na-Mt dosage of $5.0 \mathrm{~g} / \mathrm{L}$ was selected as the most efficient dosage for the adsorption process. 


\subsection{Thermocatalytic Oxidation with KPS and SPC}

\subsubsection{SPC Releasing Mechanism}

In the previous section, it was observed that the adsorption process was efficient for the removal of organic matter from WW. However, in order to achieve more substantial values an additional process is required. Therefore, a thermocatalytic oxidation process was performed in this work, in which potassium persulfate (KPS) was used in combination with sodium percarbonate (SPC) as oxidant agents. To decrease the use of iron, high temperatures were used for the activation of the oxidants. However, in order to perform this treatment, it was first necessary to understand the dissociation of SPC in water as observed in Equations (3) and (4) [59]. Table 4 shows an assay, in which SPC was applied under different concentrations $(0.1-1.0 \mathrm{~g} / \mathrm{L})$ in water. The results showed that the theoretical $\mathrm{H}_{2} \mathrm{O}_{2}$ concentration was very similar to the measured $\mathrm{H}_{2} \mathrm{O}_{2}$ concentration, by titanium (IV) oxysulfate. TOC results showed a significant decrease from 1.226 to 1.039 to $0.0 \mathrm{mg}$ $\mathrm{C} / \mathrm{L}$, respectively, for $0.1,0.5$ and $1.0 \mathrm{~g} / \mathrm{L}$ of SPC. These results were in agreement to Cui et al. [32], who observed the decomposition of SPC into $\mathrm{CO}_{2}$, water and small amounts of sodium carbonate.

$$
\begin{gathered}
\mathrm{Na}_{2} \mathrm{CO}_{3}+1.5 \mathrm{H}_{2} \mathrm{O}_{2} \rightarrow \mathrm{Na}_{2} \mathrm{CO}_{3}+1.5 \mathrm{H}_{2} \mathrm{O}_{2} \\
1.5 \mathrm{H}_{2} \mathrm{O}_{2} \rightarrow 1.5 \mathrm{H}_{2} \mathrm{O}+0.75 \mathrm{O}_{2}
\end{gathered}
$$

Table 4. Sodium percarbonate release mechanism.

\begin{tabular}{cccc}
\hline$[\mathrm{SPC}]$ & {$\left[\mathrm{H}_{\mathbf{2}} \mathbf{O}_{\mathbf{2}}\right]$ Theoretical } & {$\left[\mathrm{H}_{\mathbf{2}} \mathbf{O}_{\mathbf{2}}\right]$ Measured } & TOC \\
\hline $\mathbf{g} / \mathrm{L}$ & $\mathbf{m g} / \mathbf{L}$ & $\mathbf{~ m g} / \mathbf{L}$ & $\mathbf{~ g ~ C / L}$ \\
\hline 0.1 & 32.5 & 22.7 & 0.000 \\
0.5 & 162.4 & 140.3 & 0.000 \\
1.0 & 324.8 & 354.5 & 0.000 \\
\hline
\end{tabular}

\subsubsection{Effect of $\mathrm{S}_{2} \mathrm{O}_{8}{ }^{2-} / \mathrm{H}_{2} \mathrm{O}_{2}$ Ratio}

In the works of Rodríguez-Chueca et al. [60,61], the WW was treated by SR-AOPs, in which sulfate radicals were activated by metallic catalysts, UV radiation and heat. Although persulfate reagent can act alone as an oxidant, its effectiveness is limited for oxidation of WW [62]. The generation of sulfate radicals during the persulfate oxidation process can be significantly investigated using different applications, such as UV radiation, heat and iron ions, as observed in Equations (5)-(7) [63], as follows:

$$
\begin{aligned}
\mathrm{S}_{2} \mathrm{O}_{8}^{2-}+h v & \rightarrow 2 \mathrm{SO}_{4}^{\bullet-} \\
\mathrm{S}_{2} \mathrm{O}_{8}^{2-}+\text { Thermal Activation } & \rightarrow 2 \mathrm{SO}_{4}^{\bullet-}\left(30^{\circ} \mathrm{C}<\mathrm{T}<90{ }^{\circ} \mathrm{C}\right) \\
\mathrm{S}_{2} \mathrm{O}_{8}^{2-}+\mathrm{Fe}^{3+} & \rightarrow 2 \mathrm{SO}_{4}^{--}+\mathrm{Fe}^{2+}
\end{aligned}
$$

The $\mathrm{SO}_{4}^{\bullet-}$ may initiate the production of other intermediate highly reactive oxygen species (ROS), such as hydroxyl radicals $\left(\mathrm{HO}^{\bullet}\right)$, as observed in Equation (8) [64], as follows:

$$
\mathrm{SO}_{4}^{\bullet-}+\mathrm{H}_{2} \mathrm{O} \rightarrow \mathrm{HSO}_{4}^{-}+\mathrm{HO}^{\bullet}
$$

However, the use of metallic catalysts for the activation of sulfate radicals have the disadvantage of leaching, becoming toxic for the environment [65]; therefore, this work tested the activation of persulfate radicals by heat without addition of metallic catalyst. In addition, $\mathrm{H}_{2} \mathrm{O}_{2}$ reagent was used to activate persulfate and initiate sulfate radicals during the oxidation of the WW. To evaluate the performance of $\mathrm{H}_{2} \mathrm{O}_{2}$ in enhancing persulfate oxidation, the ratio $\mathrm{S}_{2} \mathrm{O}_{8}^{2-} / \mathrm{H}_{2} \mathrm{O}_{2}(1: 0 ; 1: 0.25 ; 1: 0.50 ; 1: 0.75 ; 1: 1 ; 1: 1.5)$ was initially studied 
under the following operational conditions: $\left[\mathrm{S}_{2} \mathrm{O}_{8}^{2-}\right]=1.0 \mathrm{~g} / \mathrm{L}, \mathrm{pH}=11.0, \mathrm{~T}=333 \mathrm{~K}$, agitation $350 \mathrm{rpm}, \mathrm{t}=2 \mathrm{~h}$.

In observation of Figure 5, without oxidant addition, thermal oxidation achieved $20.6 \%$ TOC removal after $2 \mathrm{~h}$ of reaction, possibly, due to the evaporation of alcohol or the degradation of some phenolic compounds present in the WW. However, the WW has recalcitrant compounds in its composition, which were not degraded by heat. With application of the oxidant agents, it was observed a TOC removal of 62.6, 63.4, 61.3, 63.3, 54.0 and $55.1 \%$, respectively. The highest TOC removal was observed with application of $\mathrm{S}_{2} \mathrm{O}_{8}^{2-} / \mathrm{H}_{2} \mathrm{O}_{2}$ ratio of $1: 0.25(\mathrm{~g} / \mathrm{g})$. With the increase in this ratio, the sulfate radicals initiated scavenging reactions for $\mathrm{HO}^{\bullet}$ radicals, thus decreasing the reactions efficiency, as observed by Equation (9) [62,66], as follows:

$$
\mathrm{SO}_{4}^{2-}+\mathrm{HO}^{\bullet} \rightarrow \mathrm{SO}_{4}^{\bullet-}+\mathrm{HO}^{-}
$$

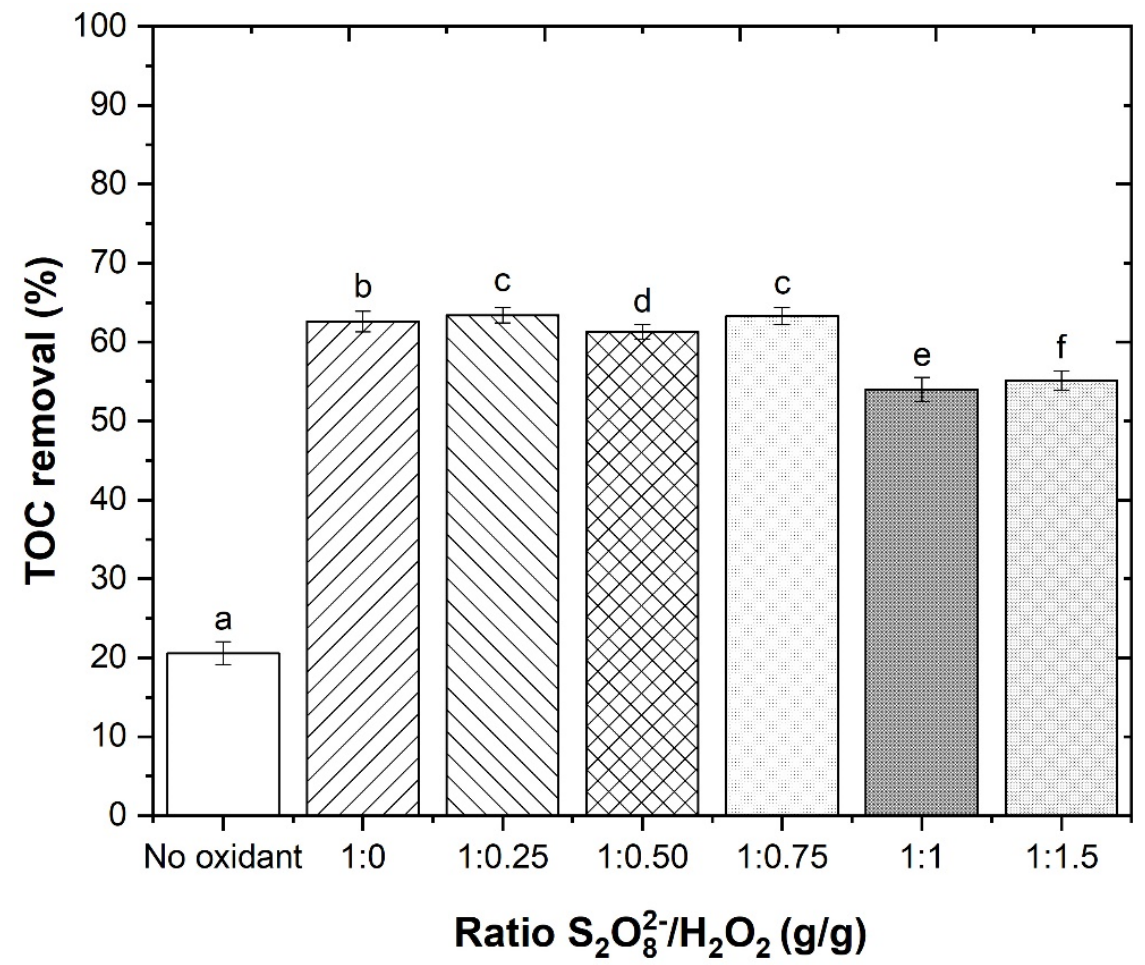

Figure 5. Evolution of TOC removal throughout different $\mathrm{S}_{2} \mathrm{O}_{8}^{2-} / \mathrm{H}_{2} \mathrm{O}_{2}$ ratio (1:0-1:1.5) in thermocatalytic oxidation, under the following operational conditions: $\left[\mathrm{S}_{2} \mathrm{O}_{8}^{2-}\right]=1.0 \mathrm{~g} / \mathrm{L}, \mathrm{pH}=11.0, \mathrm{~T}=333 \mathrm{~K}$, agitation $350 \mathrm{rpm}, \mathrm{t}=2 \mathrm{~h}$. A blank experiment under the following operational conditions is also shown as reference: $\mathrm{pH}=11.0, \mathrm{~T}=333 \mathrm{~K}$, agitation $350 \mathrm{rpm}, \mathrm{t}=2 \mathrm{~h}$. Means in bars with different letters represent significant differences $(p<0.05)$ between each ratio.

Therefore, based in these results, the ratio 1:0.25 $(\mathrm{g} / \mathrm{g}) \mathrm{S}_{2} \mathrm{O}_{8}^{2-} / \mathrm{H}_{2} \mathrm{O}_{2}$ was selected as the best ratio.

\subsubsection{Effect of $\mathrm{S}_{2} \mathrm{O}_{8}{ }^{2-} / \mathrm{H}_{2} \mathrm{O}_{2}$ Dosage}

In the previous section it was observed that the ratio of $\mathrm{S}_{2} \mathrm{O}_{8}^{2-} / \mathrm{H}_{2} \mathrm{O}_{2}$ had a high influence in the TOC removal of WW. In this section the dosage of $\mathrm{S}_{2} \mathrm{O}_{8}^{2-} / \mathrm{H}_{2} \mathrm{O}_{2}$ was varied (0.1:0.025; $0.5: 0.125 ; 1: 0.25 ; 1.5: 0.375 ; 2: 0.5)$ under the following operational conditions: $\mathrm{S}_{2} \mathrm{O}_{8}^{2-} / \mathrm{H}_{2} \mathrm{O}_{2}$ ratio $=1: 0.25, \mathrm{pH}=11.0, \mathrm{~T}=333 \mathrm{~K}$, agitation $350 \mathrm{rpm}, \mathrm{t}=2 \mathrm{~h}$. By observation of Figure 6, there was a TOC removal of 63.4, 59.2, 63.4, 56.4 and 59.0\%, respectively, for $0.1: 0.025 ; 0.5: 0.125 ; 1: 0.25 ; 1.5: 0.375 ; 2: 0.5$. These results showed that by decreasing the oxidant concentrations from 1:0.25 to $0.1: 0.025 \mathrm{~g} / \mathrm{g}$, the TOC removal was similar. However, 
by increasing $\mathrm{S}_{2} \mathrm{O}_{8}^{2-} / \mathrm{H}_{2} \mathrm{O}_{2}$ dosage to 2:0.5 $\mathrm{g} / \mathrm{g}$, the TOC removal had a higher decrease. These results were different than those observed in the work of Hilles et al. [63], who required an increase in $\mathrm{S}_{2} \mathrm{O}_{8}^{2-} / \mathrm{H}_{2} \mathrm{O}_{2}$ dosage to achieve higher COD removal for landfill leachate treatment. One explanation for these results could be the reduction of scavenging reactions by sulfate and hydroxyl radicals, as previously observed Hilles et al. [66].

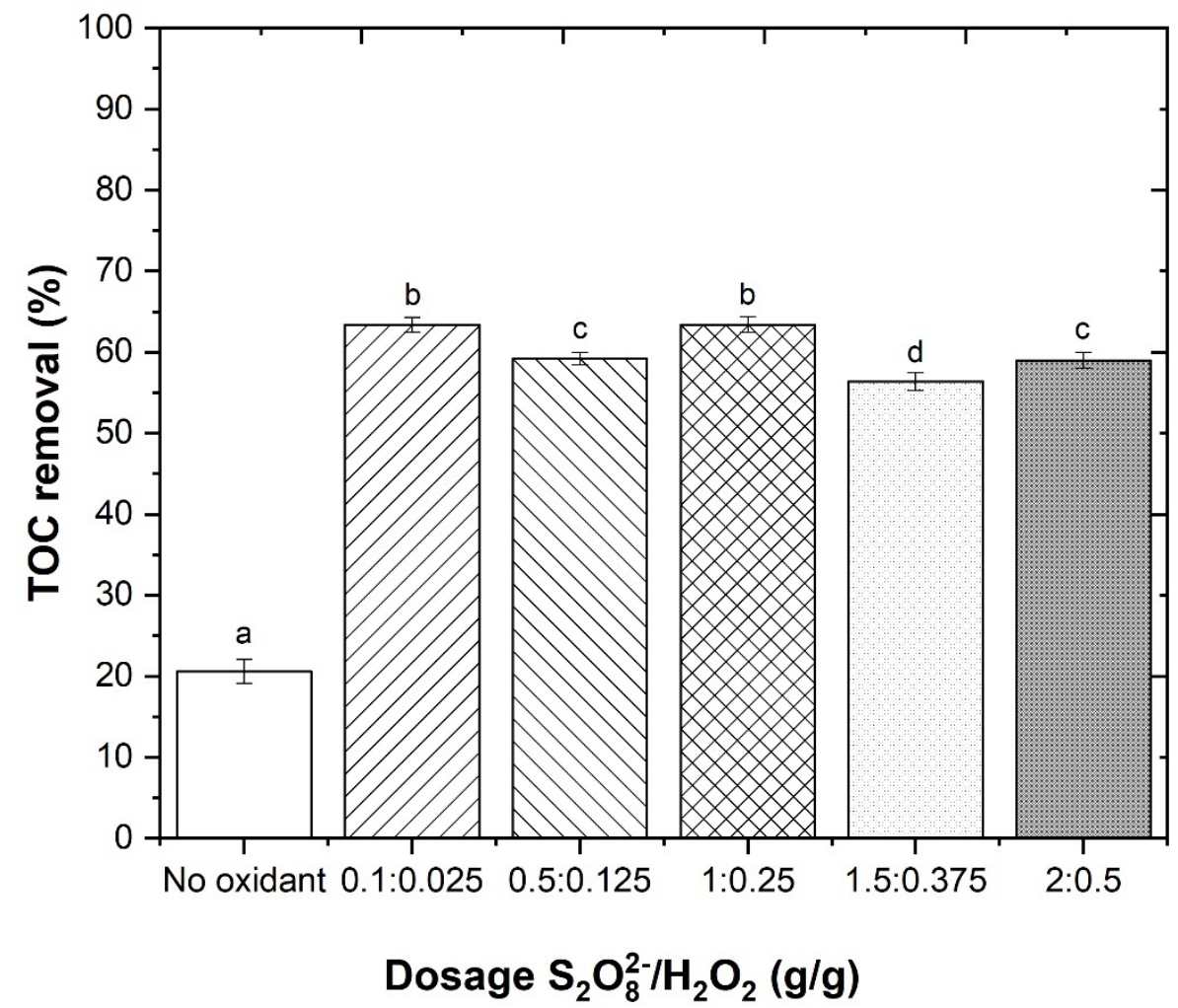

Figure 6. Evolution of TOC removal throughout different $\mathrm{S}_{2} \mathrm{O}_{8}^{2-} / \mathrm{H}_{2} \mathrm{O}_{2}$ dosage $(0.1: 0.025-2: 0.5 \mathrm{~g} / \mathrm{g}$ ) in thermocatalytic oxidation, under the following operational conditions: $\mathrm{S}_{2} \mathrm{O}_{8}^{2-} / \mathrm{H}_{2} \mathrm{O}_{2}$ ratio $=1: 0.25$, $\mathrm{pH}=11.0, \mathrm{~T}=333 \mathrm{~K}$, agitation $350 \mathrm{rpm}, \mathrm{t}=2 \mathrm{~h}$. A blank experiment under the following operational conditions is also shown as reference: $\mathrm{pH}=11.0, \mathrm{~T}=333 \mathrm{~K}$, agitation $350 \mathrm{rpm}, \mathrm{t}=2 \mathrm{~h}$. Means in bars with different letters represent significant differences $(p<0.05)$ between each dosage.

Therefore, based in these results, $\mathrm{S}_{2} \mathrm{O}_{8}^{2-} / \mathrm{H}_{2} \mathrm{O}_{2}$ dosage 0.1:0.025 $\mathrm{g} / \mathrm{g}$ was selected as the best dosage.

\subsubsection{Effect of $\mathrm{pH}$}

After the determination of the best dosage of $\mathrm{S}_{2} \mathrm{O}_{8}^{2-} / \mathrm{H}_{2} \mathrm{O}_{2}$ for thermocatalytic oxidation treatment of WW, it was necessary to optimize the $\mathrm{pH}$ of the reaction. In the work of Candia-Onfray et al. [67], the SR-AOPs were performed at $\mathrm{pH}$ 5.6. However, in the work of Rodríguez-Chueca et al. [61], the SR-AOPs were performed at $\mathrm{pH} 6.5$ for the treatment of winery wastewater. Due to the large $\mathrm{pH}$ spectrum of SR-AOP action, in this section different $\mathrm{pH}$ values $(3.0,5.0,7.0,9.0,11.0)$ were tested under the following operational conditions: $\mathrm{S}_{2} \mathrm{O}_{8}^{2-} / \mathrm{H}_{2} \mathrm{O}_{2}$ ratio $=1: 0.25, \mathrm{~S}_{2} \mathrm{O}_{8}^{2-} / \mathrm{H}_{2} \mathrm{O}_{2}$ dosage $=0.1: 0.025(\mathrm{~g} / \mathrm{g}), \mathrm{T}=333 \mathrm{~K}$, agitation $350 \mathrm{rpm}, \mathrm{t}=2 \mathrm{~h}$. Figure 7, shows a TOC removal of 59.4, 60.7, 60.4, 52.8 and $63.4 \%$, respectively, after $2 \mathrm{~h}$ of reaction, for $\mathrm{pH} 3.0,5.0,7.0,9.0$ and 11.0. With the increase in $\mathrm{pH}$ from 3.0 to 11.0 an increase in TOC removal was observed, which was expected, because in the work of Hilles et al. [63], the increase in $\mathrm{pH}$ in the $\mathrm{S}_{2} \mathrm{O}_{8}^{2-} / \mathrm{H}_{2} \mathrm{O}_{2}$ system lead to higher COD removal in the treatment of landfill leachate. At high $\mathrm{pH}$ conditions $(\mathrm{pH} 11.0)$, the alkaline activation was very productive in generating sulfate ions and hydroxyl radicals, which have high oxidation potential $\left(\mathrm{E}_{\mathrm{HO}}^{\mathrm{O}} \cdot=2.80 \mathrm{~V}^{\circ}\right.$ and $\left.\mathrm{E}_{\mathrm{SO}_{4}^{-}}^{\mathrm{O}}=2.70 \mathrm{~V}\right)[19]$. 
Furman et al. [68] also observed that persulfate's efficiency in oxidation processes increased in alkaline conditions. For base activation of persulfate, a nucleophilic attack on the O-O bond is considered as the main mechanism as observed in Equations (10) and (11) [19]. The perhydroxyl radicals $\left(\mathrm{HO}_{2}^{\bullet}\right)$ plays a key role in the production of sulfate radicals. At acidic $\mathrm{pH}$, the superoxide radicals tend to react with hydrogen ions to form perhydroxyl radicals, while at alkaline $\mathrm{pH}$, perhydroxyl radicals tends to decompose into superoxide radicals. Due to alkaline conditions, the sulfate radicals are transformed into hydroxyl radicals as observed in Equation (12) [69], as follows:

$$
\begin{gathered}
\mathrm{S}_{2} \mathrm{O}_{8}^{2-}+\mathrm{H}_{2} \mathrm{O}_{2} \rightarrow 2 \mathrm{SO}_{4}^{2-}+\mathrm{HO}_{2}^{-}+\mathrm{H}^{+} \\
\mathrm{S}_{2} \mathrm{O}_{8}^{2-}+\mathrm{HO}_{2}^{-} \rightarrow \mathrm{SO}_{4}^{2-}+\mathrm{SO}_{4}^{\bullet-}+\mathrm{O}_{2}^{\bullet-}+\mathrm{H}^{+} \\
\mathrm{SO}_{4}^{\bullet-}+\mathrm{HO}^{-} \rightarrow \mathrm{SO}_{4}^{2-}+\mathrm{HO}^{\bullet}
\end{gathered}
$$

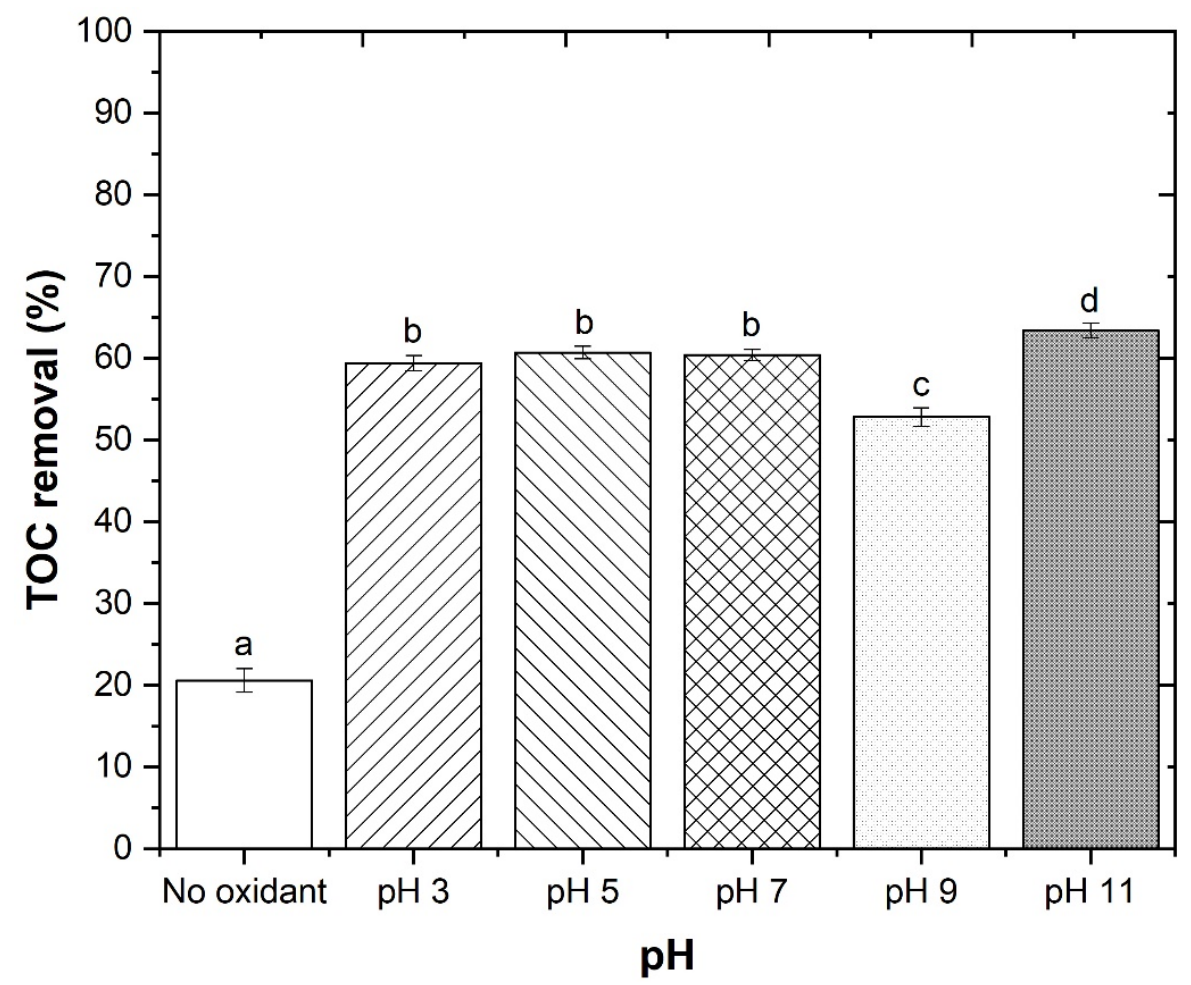

Figure 7. Evolution of TOC removal at different $\mathrm{pH}$ (3.0-11.0) in thermocatalytic oxidation, under the following operational conditions: $\mathrm{S}_{2} \mathrm{O}_{8}^{2-} / \mathrm{H}_{2} \mathrm{O}_{2}$ ratio = 1:0.25, $\mathrm{S}_{2} \mathrm{O}_{8}^{2-} / \mathrm{H}_{2} \mathrm{O}_{2}$ dosage = 0.1:0.025 $(\mathrm{g} / \mathrm{g})$, $\mathrm{T}=333 \mathrm{~K}$, agitation $350 \mathrm{rpm}, \mathrm{t}=2 \mathrm{~h}$. A blank experiment under the following operational conditions is also shown as reference: $\mathrm{pH}=11.0, \mathrm{~T}=333 \mathrm{~K}$, agitation $350 \mathrm{rpm}, \mathrm{t}=2 \mathrm{~h}$. Means in bars with different letters represent significant differences $(p<0.05)$ between each $\mathrm{pH}$.

Despite the high TOC removal at $\mathrm{pH} 11.0$, there were several associated disadvantages, such as (1) the high cost in reagents to achieve $\mathrm{pH} 11.0$ and (2) the Portuguese law No. 236/98 for residual water discharge for the $\mathrm{pH}$ of the treated wastewater is 6.0 to 9.0. Considering the similar TOC removal between pH 7.0 (60.4\%) and pH 11 (63.4\%), pH 7.0 was selected as the best $\mathrm{pH}$.

\subsubsection{Effect of Temperature}

The bond energy of $\mathrm{O}-\mathrm{O}$ of persulfate is estimated to be in the range of $140-213.3 \mathrm{~kJ} / \mathrm{mol}$. The essential mechanism of persulfate activation is the fission of $\mathrm{O}-\mathrm{O}$ bond in the structure of persulfate. For heat activation, the energy input by the high temperature $\left(>50^{\circ} \mathrm{C}\right)$ can cause the fission of $\mathrm{O}-\mathrm{O}$ bond to form the sulfate radicals, as observed by Equation (7) [19]. The 
hydroxyl radicals are the main radicals produced during the heat activation of persulfate, indicating that sulfate radicals are quickly transformed into hydroxyl radicals, as observed in Equation (13) [70], as follows:

$$
\mathrm{SO}_{4}^{\bullet-}+\mathrm{H}_{2} \mathrm{O} \rightarrow \mathrm{SO}_{4}^{2-}+\mathrm{HO}^{\bullet}+\mathrm{H}^{+}
$$

Therefore, in this section the effect of temperature variation $(303,313,323,333$ and $343 \mathrm{~K}$ ) was studied under the following operational conditions: $\mathrm{S}_{2} \mathrm{O}_{8}^{2-} / \mathrm{H}_{2} \mathrm{O}_{2}$ ratio $=1: 0.25$, $\mathrm{S}_{2} \mathrm{O}_{8}^{2-} / \mathrm{H}_{2} \mathrm{O}_{2}$ dosage $=0.1: 0.025(\mathrm{~g} / \mathrm{g}), \mathrm{pH}=7.0$, agitation $350 \mathrm{rpm}, \mathrm{t}=2 \mathrm{~h}$. Initial blank experiments were performed without addition of oxidant (Figure 8) and a TOC removal of $39.7,48.0,59.2,20.6$ and $63.4 \%$, respectively, was observed. With the increase in temperature, an increase in TOC removal was observed, which indicated that there were organic compounds susceptible to heat. When oxidant agents $\left(\mathrm{S}_{2} \mathrm{O}_{8}^{2-} / \mathrm{H}_{2} \mathrm{O}_{2}\right)$ were added, an increase in TOC removal to $52.9,53.0,60.2,60.4$ and $65.6 \%$, respectively, was observed. These results were similar to the work of Rodríguez-Chueca et al. [61], who observed that when increasing the temperature, the efficiency of oxidation reaction of sulfate radicals increased in COD removal of WW. In the work of Zrinyi and Pham [71], it was observed that phenol degradation by sulfate radicals was more efficient at $343 \mathrm{~K}$, which is in agreement with this work.

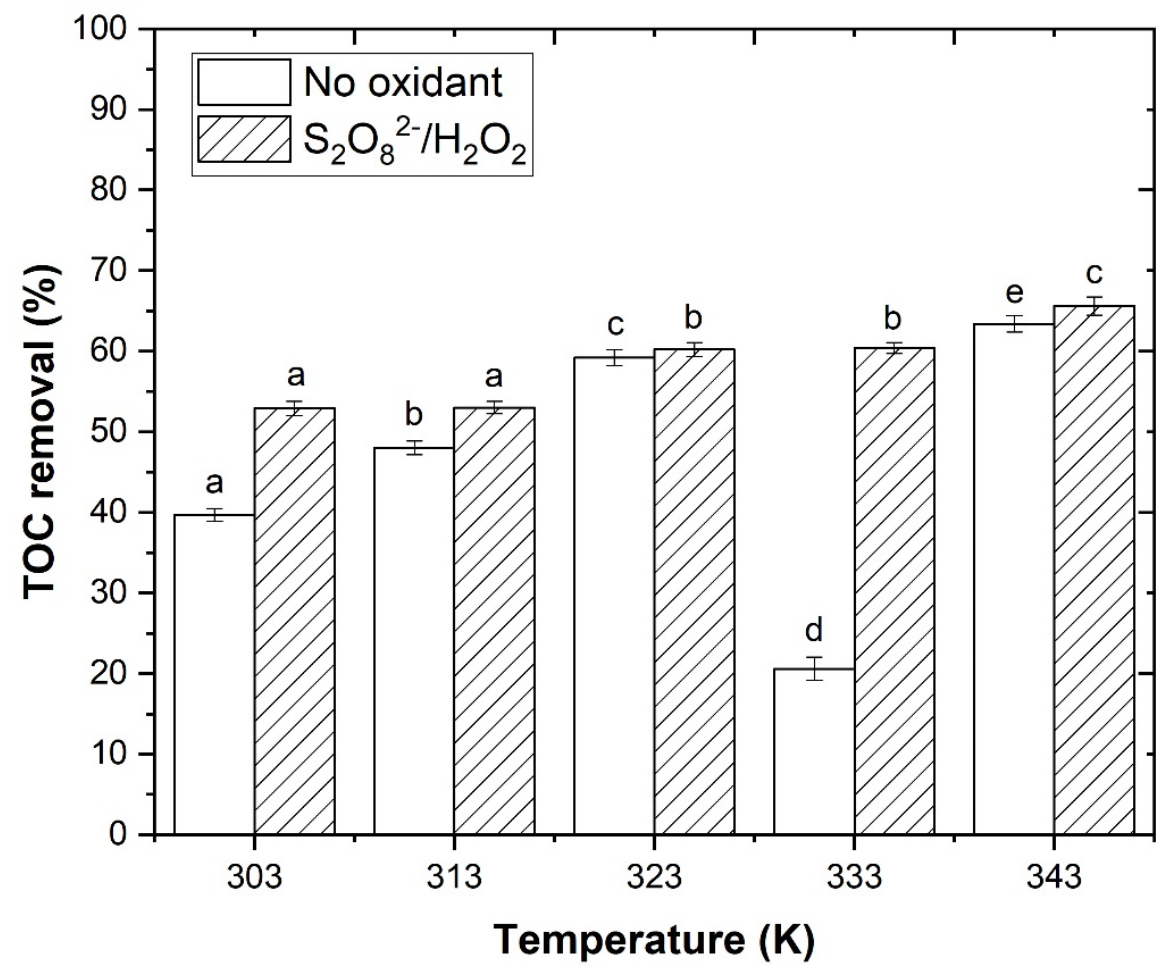

Figure 8. Evolution of TOC removal at different temperatures (303-343 K) in thermocatalytic oxidation, under the following operational conditions: $\mathrm{S}_{2} \mathrm{O}_{8}^{2-} / \mathrm{H}_{2} \mathrm{O}_{2}$ ratio $=1: 0.25, \mathrm{~S}_{2} \mathrm{O}_{8}^{2-} / \mathrm{H}_{2} \mathrm{O}_{2}$ dosage $=0.1: 0.025(\mathrm{~g} / \mathrm{g}), \mathrm{pH}=7.0$, agitation $350 \mathrm{rpm}, \mathrm{t}=2 \mathrm{~h}$. Blank experiments at different temperatures (303-343 K) are also shown as reference, under the following operational conditions: $\mathrm{pH}=7.0$, agitation $350 \mathrm{rpm}, \mathrm{t}=2 \mathrm{~h}$. Means in bars with different letters represent significant differences $(p<0.05)$ between each process (Blank and thermocatalytic oxidation) by comparing temperatures.

Therefore, based in these results, $343 \mathrm{~K}$ was selected as the best temperature for sulfate radical activation.

\subsection{Combination of Adsorption with Thermocatalytic Oxidation}

In previous sections, it was observed that application of Na-Mt in the adsorption process had high efficiency in the removal of organic carbon from WW. This work also 
tested the application of a thermocatalytic process, in which high temperatures and $\mathrm{H}_{2} \mathrm{O}_{2}$ in the form of SPC were used to activate persulfate radicals, to degrade organic carbon from the WW. The results also showed a high efficiency from this treatment; however, there were some limitations such as high levels of turbidity, TSS and total polyphenols (Table 1), which could have decreased the thermocatalytic oxidation efficiencies. Given the results obtained individually, it will be interesting to study the combination of the two previous processes. In this context, the combination of adsorption process with bentonite was tested in the optimal conditions obtained previously, as follows: [Na-Mt] $=5.0 \mathrm{~g} / \mathrm{L}, \mathrm{pH}=3.0$, $\mathrm{V}=500 \mathrm{~mL}$, agitation $350 \mathrm{rpm}, \mathrm{T}=298 \mathrm{~K}, \mathrm{t}=24 \mathrm{~h}$, with thermocatalytic oxidation best conditions, as follows: $\mathrm{S}_{2} \mathrm{O}_{8}^{2-} / \mathrm{H}_{2} \mathrm{O}_{2}$ ratio $=1: 0.25, \mathrm{~S}_{2} \mathrm{O}_{8}^{2-} / \mathrm{H}_{2} \mathrm{O}_{2}$ dosage $=0.1: 0.025(\mathrm{~g} / \mathrm{g})$, $\mathrm{pH}=7.0, \mathrm{~T}=343 \mathrm{~K}$, agitation $350 \mathrm{rpm}, \mathrm{t}=2 \mathrm{~h}$ ). In observation of Figure $9 \mathrm{a}$, the adsorption process had a TOC, COD and a BOD 5 removal of 61.1, 68.4 and 40.7\%, respectively. With application of thermocatalytic process, the removals increased to 76.7, 81.4 and $81.7 \%$, respectively. Clearly, the combination of adsorption and thermocatalytic oxidation achieved higher removals than both processes alone. One possible reason for the increased efficiency could be the reduction of interferents present in the WW, such as the turbidity, TSS and total polyphenols. In Figure 9b, turbidity, TSS and total polyphenols reduction of 81.4, 94.3 and $99.4 \%$ were observed, respectively. After the thermocatalytic oxidation the removals increased to $92.6,98.1$ and $99.9 \%$, respectively. These results were in agreement with the work of Jaafarzadeh et al. [72], who observed an increase in sulfate radicals efficiency in COD removal of pulp and paper wastewater after reduction of TSS and color reduction. In accordance with Amor et al. [73], the high turbidity, TSS and total polyphenols are considered to be hydroxyl radical scavengers.
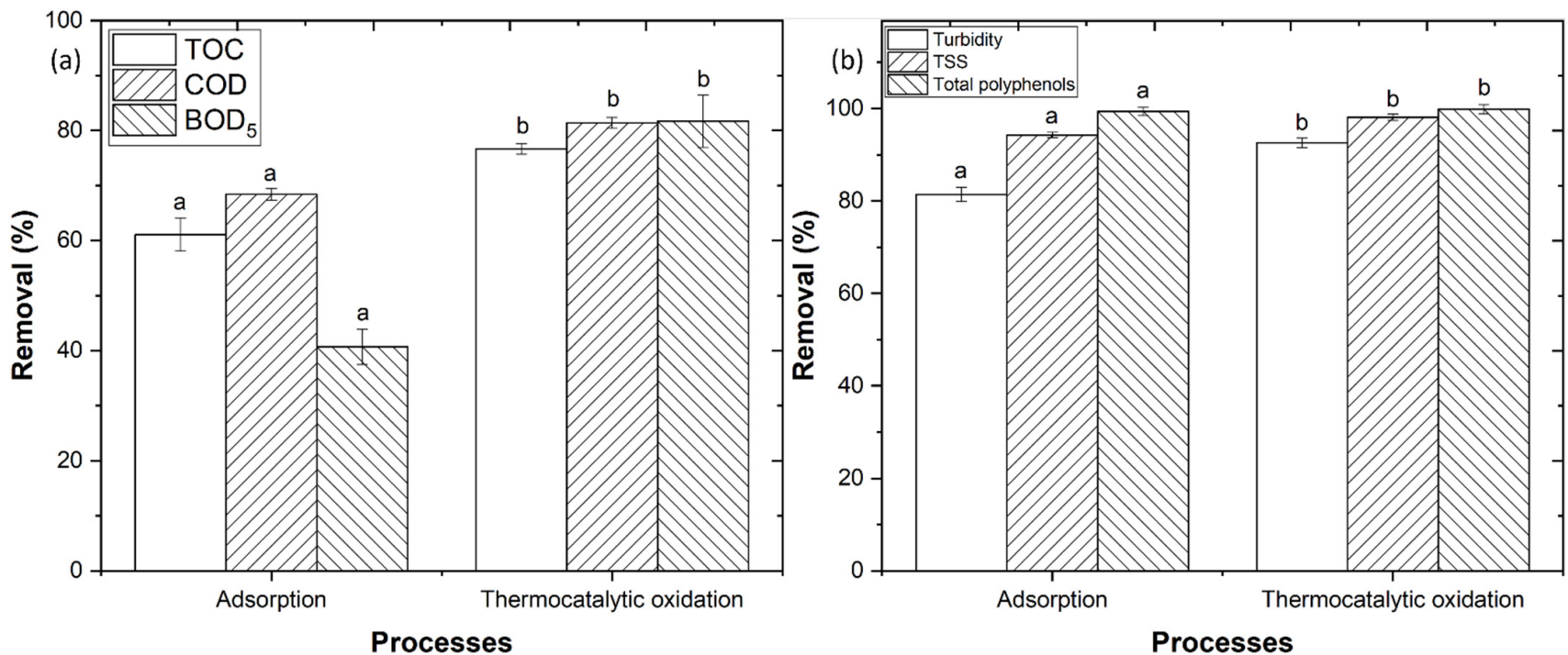

Figure 9. Overall results after adsorption process and thermocatalytic oxidation processes in (a) TOC, $\mathrm{COD}$ and $\mathrm{BOD}_{5}$ removal and (b) turbidity, TSS and total polyphenols. Adsorption operational conditions, as follows: [Na-Mt] $=5.0 \mathrm{~g} / \mathrm{L}, \mathrm{pH}=3.0, \mathrm{~V}=500 \mathrm{~mL}$, agitation $350 \mathrm{rpm}, \mathrm{T}=298 \mathrm{~K}$, $\mathrm{t}=24 \mathrm{~h}$. Thermocatalytic oxidation conditions, as follows: $\mathrm{S}_{2} \mathrm{O}_{8}^{2-} / \mathrm{H}_{2} \mathrm{O}_{2}$ ratio $=1: 0.25, \mathrm{~S}_{2} \mathrm{O}_{8}^{2-} / \mathrm{H}_{2} \mathrm{O}_{2}$ dosage $=0.1: 0.025(\mathrm{~g} / \mathrm{g}), \mathrm{pH}=7.0, \mathrm{~T}=343 \mathrm{~K}$, agitation $350 \mathrm{rpm}, \mathrm{t}=2 \mathrm{~h}$. Means in bars with different letters represent significant differences $(p<0.05)$ between each parameter (TOC, $\mathrm{COD}, \mathrm{BOD}_{5}$, turbidity, TSS and total polyphenols) by comparing wastewaters.

\subsection{Phytotoxicity Tests}

It was observed that the combination of adsorption process with Na-Mt and thermocatalytic oxidation with $\mathrm{S}_{2} \mathrm{O}_{8}^{2-} / \mathrm{H}_{2} \mathrm{O}_{2}$ was beneficial for the reduction of organic carbon present in the WW. However, its effect in the germination of plants is still unknown. Therefore, the phytotoxic effect of raw WW, adsorption and combined adsorption-thermocatalytic 
oxidation on germination of seeds from two Dicotyledonae (lettuce and cucumber) and two Monocotyledonae (corn and onion) were evaluated, similar to the works of Casa et al. [74] and Mosse et al. [75]. For the determination of the germination index, the seed germination and root elongation (Equation (1)) were considered, which explains results above $100 \%$.

In Figure 10, it was observed that raw WW posed a phytotoxicity effect to onion and lettuce seeds (GI $=58$ and $0 \%$ ), regarding cucumber and corn seeds (106 and 178\%, respectively). With application of combined adsorption-thermocatalytic oxidation, an increase in the GI to 176, 134, 250 and $269 \%$, respectively, was observed for onion, cucumber, lettuce and corn seeds (GI > 80\%), which showed that these treatments had a low phytotoxic effect for germination of plants. In the work of Rizzo et al. [76], it was observed that application of an adsorption process for the removal of contaminants increased the germination index of plant seeds, thus decreasing the phytotoxicity of the wastewater, similar to the results obtained in this work. These results evidence the suitability of the combination of adsorption and thermocatalytic oxidation for the reduction of phytotoxicity in seed germination.

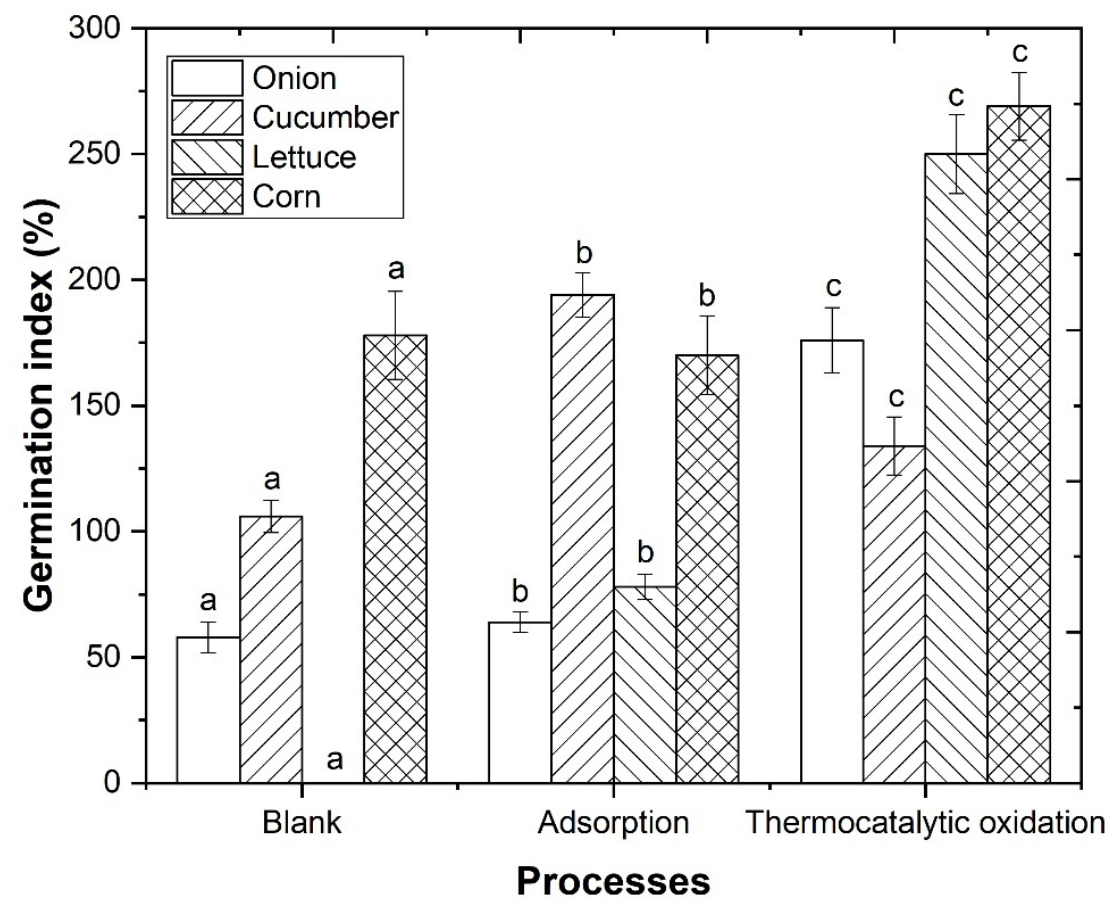

Figure 10. Analysis of seed phytotoxicity after wastewater treatment, by evaluation of germination index (GI). Adsorption operational conditions, as follows: [Na-Mt] $=5.0 \mathrm{~g} / \mathrm{L}, \mathrm{pH}=3.0, \mathrm{~V}=500 \mathrm{~mL}$, agitation $350 \mathrm{rpm}, \mathrm{T}=298 \mathrm{~K}, \mathrm{t}=24 \mathrm{~h}$. Thermocatalytic oxidation conditions, as follows: $\mathrm{S}_{2} \mathrm{O}_{8}^{2-} / \mathrm{H}_{2} \mathrm{O}_{2}$ ratio $=1: 0.25, \mathrm{~S}_{2} \mathrm{O}_{8}^{2-} / \mathrm{H}_{2} \mathrm{O}_{2}$ dosage $=0.1: 0.025(\mathrm{~g} / \mathrm{g}), \mathrm{pH}=7.0, \mathrm{~T}=343 \mathrm{~K}$, agitation $350 \mathrm{rpm}, \mathrm{t}=2 \mathrm{~h}$. $\mathrm{GI} \leq 50 \%$ (high concentration of phytotoxic substances), $80 \%<\mathrm{GI}>50 \%$ (moderated presence of phytotoxic substances), GI $\geq 80 \%$ (there are no phytotoxic substances, or they exist in very small dosages). Means in bars with different letters represent significant differences $(p<0.05)$ between each process (blank, adsorption and thermocatalytic oxidation) by comparing different plant seeds.

As previously observed by Santos et al. [77], polyphenols are responsible for the toxicity of the WW, and their removal by both treatments could have potentiated the increase in the germination index; therefore, the phenolic content of the WW was evaluated (Figure 11), as well as the efficiency of both treatments in its removal. In Figure 11, a high content of total phenols, non-flavonoids and flavonoids (192, 112 and $80 \mathrm{mg}$ gallic acid/L, respectively) was observed, which is in agreement to the work of Li and Sun [78], who observed the presence of these compounds in grapes and red wine. 


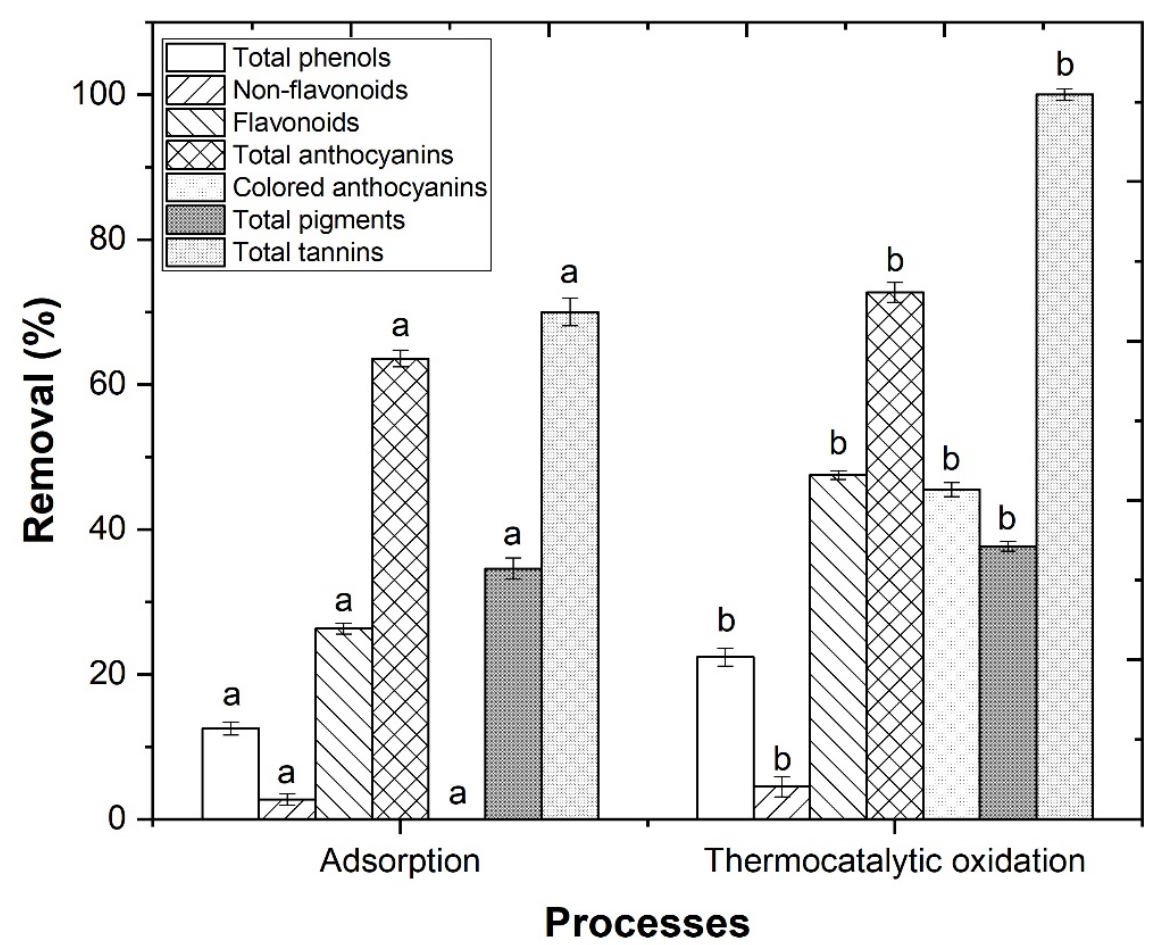

Figure 11. Analysis of phenolic composition after adsorption process and combined adsorptionthermocatalytic oxidation processes. Adsorption operational conditions, as follows: $[\mathrm{Na}-\mathrm{Mt}]=5.0 \mathrm{~g} / \mathrm{L}$, $\mathrm{pH}=3.0, \mathrm{~V}=500 \mathrm{~mL}$, agitation $350 \mathrm{rpm}, \mathrm{T}=298 \mathrm{~K}, \mathrm{t}=24 \mathrm{~h}$. Thermocatalytic oxidation conditions, as follows: $\mathrm{S}_{2} \mathrm{O}_{8}^{2-} / \mathrm{H}_{2} \mathrm{O}_{2}$ ratio $=1: 0.25, \mathrm{~S}_{2} \mathrm{O}_{8}^{2-} / \mathrm{H}_{2} \mathrm{O}_{2}$ dosage $=0.1: 0.025(\mathrm{~g} / \mathrm{g}), \mathrm{pH}=7.0, \mathrm{~T}=343 \mathrm{~K}$, agitation $350 \mathrm{rpm}, \mathrm{t}=2 \mathrm{~h}$. Means in bars with different letters represent significant differences $(p<0.05)$ between each parameter (total phenols, non-flavonoids, flavonoids, total anthocyanins, colored anthocyanins, total pigments and total tannins) by comparing wastewaters.

In Figure 11, the presence of total anthocyanins $(11 \mathrm{mg} / \mathrm{L})$ was observed, which was responsible for the red color of the WW [42]. In accordance with Cheynier et al. [79] the red color is not only derived from anthocyanins, but also from the conversion of grape anthocyanins into other pigments in a process called copigmentation. This was also in agreement with the data from this work, since a certain amount of polymeric and total pigments was also detected ( 0.81 and $1.62 \mathrm{mg} / \mathrm{L}$ respectively).

Another factor which could have an influence on the red color of the WW was the presence of tannins in a large concentration $(97 \mathrm{mg} / \mathrm{L})$ which formed tannin-anthocyanin adducts with intense red color [79].

Considering that there are no studies regarding the effect of adsorption and combined adsorption-thermocatalytic oxidation processes in the removal of phenolic compounds of WW, it was evaluated the removal of total phenols, non-flavonoids, flavonoids, total anthocyanins, colored anthocyanins, total pigments and total tannins.

In Figure 11, a removal of 12.5, 2.7, 26.3, 63.6, 0.0, 34.6 and 70.0\%, respectively, by adsorption process was observed. With application of combined adsorption-thermocatalytic oxidation process, it was observed a removal of $22.4,4.5,47.5,72.7,45.5,37.7$ and $100 \%$, respectively. The reduction of these phenolic compounds had an effect on the removal of color from the WW, which was evaluated by a CIELab analysis (Table 5), similar to the work of Jorge et al. [38]. 
Table 5. Analysis of chromatic characteristics (CIELab) after adsorption process and combined adsorption-thermocatalytic oxidation processes. Adsorption operational conditions, as follows: [Na-Mt] $=5.0 \mathrm{~g} / \mathrm{L}, \mathrm{pH}=3.0, \mathrm{~V}=500 \mathrm{~mL}$, agitation $350 \mathrm{rpm}, \mathrm{T}=298 \mathrm{~K}, \mathrm{t}=24 \mathrm{~h}$. Thermocatalytic oxidation conditions, as follows: $\mathrm{S}_{2} \mathrm{O}_{8}^{2-} / \mathrm{H}_{2} \mathrm{O}_{2}$ ratio $=1: 0.25, \mathrm{~S}_{2} \mathrm{O}_{8}^{2-} / \mathrm{H}_{2} \mathrm{O}_{2}$ dosage = 0.1:0.025 $(\mathrm{g} / \mathrm{g})$, $\mathrm{pH}=7.0, \mathrm{~T}=343 \mathrm{~K}$, agitation $350 \mathrm{rpm}, \mathrm{t}=2 \mathrm{~h}$. Means in the same column with different letters represent significant differences $(p<0.05)$ within each parameter by comparing the different processes.

\begin{tabular}{|c|c|c|c|c|c|c|c|c|}
\hline Processes & Time & $\mathbf{L}$ & a & $\mathbf{b}$ & $\Delta L$ & $\Delta \mathbf{a}$ & $\Delta \mathrm{b}$ & $\Delta E_{\mathrm{ab}}$ \\
\hline & (hours) & $(\%)$ & & & & & & \\
\hline Blank & 0 & $5.9 \pm 1.7 \mathrm{a}$ & $3.26 \pm 1.3 \mathrm{a}$ & $3.60 \pm 1.5 \mathrm{a}$ & & & & \\
\hline Adsorption & 24 & $90.5 \pm 0.4 b$ & $0.93 \pm 0.5 b$ & $2.86 \pm 1.9 b$ & $84.5 \pm 0.8 \mathrm{a}$ & $-2.33 \pm 1.0 \mathrm{a}$ & $-0.74 \pm 1.2 \mathrm{a}$ & $84.58 \pm 0.3 \mathrm{a}$ \\
\hline $\begin{array}{c}\text { Thermocatalytic } \\
\text { oxidation }\end{array}$ & 26 & $95.5 \pm 0.2 c$ & $1.02 \pm 1.4 b$ & $8.34 \pm 1.5 c$ & $89.6 \pm 0.4 b$ & $-2.24 \pm 1.6 b$ & $4.74 \pm 3.5 \mathrm{~b}$ & $89.71 \pm 0.9 b$ \\
\hline
\end{tabular}

With application of adsorption and combined adsorption-thermocatalytic oxidation processes it were observed negative values for $\Delta \mathrm{a}(-2.33$ and -2.24 , respectively), which indicated a reduction of the red color. An increase in the luminosity of the raw WW from $5.9 \%$ to 90.5 and $95.5 \%$, respectively was also observed after adsorption and combined adsorption-thermocatalytic processes, which meant that the phenolic compounds were directly linked to the dark red color of the wastewater. The color removal, given by the Euclidean distance was 84.6 and 89.7 after adsorption and combined adsorptionthermocatalytic oxidation processes, meaning that color removal was perceptible to the human eye in accordance with Spagna et al. [45].

\section{Conclusions}

In this work, two processes were applied for the treatment of WW: adsorption and thermocatalytic oxidation processes. For the adsorption process activated sodium bentonite (Na-Mt) was used, which showed great swelling properties and a high capacity for COD removal from the WW. For the thermocatalytic oxidation process, the sulfate radicals were activated by high temperatures, without metal catalyst, to avoid the production of metal sludge. In addition, to increase the activation of sulfate radicals, $\mathrm{H}_{2} \mathrm{O}_{2}$ was applied in solid form, by addition of sodium percarbonate (SPC). Considering the objectives defined for this work, the main conclusions are:

1. The adsorption process in bentonite is a very efficient process for organic carbon reduction. Under the best operational conditions: [Na-Mt] $=5.0 \mathrm{~g} / \mathrm{L}, \mathrm{pH}=3.0$, $\mathrm{V}=500 \mathrm{~mL}$, agitation $350 \mathrm{rpm}, \mathrm{T}=298 \mathrm{~K}, \mathrm{t}=24 \mathrm{~h}$, there is a TOC removal of $61.1 \%$;

2. The sodium percarbonate (SPC) is able to release $\mathrm{H}_{2} \mathrm{O}_{2}$ into water and the carbonate is evaporated as $\mathrm{CO}_{2}$;

3. The sulfate radicals can be activated at high temperatures $(\mathrm{T}=343 \mathrm{~K})$. Under the best operational conditions: $\mathrm{S}_{2} \mathrm{O}_{8}^{2-} / \mathrm{H}_{2} \mathrm{O}_{2}$ ratio $=1: 0.25, \mathrm{~S}_{2} \mathrm{O}_{8}^{2-} / \mathrm{H}_{2} \mathrm{O}_{2}$ dosage $=0.1: 0.025(\mathrm{~g} / \mathrm{g})$, $\mathrm{pH}=7.0, \mathrm{~T}=343 \mathrm{~K}$, agitation $350 \mathrm{rpm}, \mathrm{t}=2 \mathrm{~h}$ achieving $65.6 \% \mathrm{TOC}$ removal;

4. The combination of adsorption-thermocatalytic oxidation processes allows efficient WW treatment with a TOC, $\mathrm{COD}$ and $\mathrm{BOD}_{5}$ removal of $76.7,81.4$ and $81.7 \%$, respectively; It is also concluded that the combination of these two processes poses no phytotoxic effect in the germination of seeds due to high germination index (GI > 80\%) observed in germination of onion, cucumber, lettuce and corn seeds;

5. The combination of adsorption-thermocatalytic oxidation processes proved to be very efficient in the removal of phenolic compounds present in the WW and the dark red color of the wastewater due to the negative value of $\Delta \mathrm{a}(-2.24)$ and high luminosity $(\mathrm{L}=95.5 \%)$.

These results showed that the combination of adsorption with bentonite and thermocatalytic processes are very promising to decrease the large content of organic carbon and phytotoxicity present in the WW. 


\begin{abstract}
Author Contributions: Conceptualization, N.J., A.R.T. and V.G.; methodology, N.J., A.R.T. and V.G.; validation, N.J. and A.R.T.; formal analysis, N.J. and A.R.T.; investigation, N.J. and A.R.T.; writingoriginal draft preparation, N.J. and A.R.T.; writing—review and editing, N.J., A.R.T., V.G., M.S.L. and J.A.P.; visualization, N.J., V.G., M.S.L. and J.A.P.; supervision, M.S.L. and J.A.P.; project administration, J.A.P. All authors have read and agreed to the published version of the manuscript.
\end{abstract}

Funding: The authors are grateful for the financial support by the Project AgriFood XXI, operation No. NORTE-01-0145-FEDER-000041, and to the Fundação para a Ciência e a Tecnologia (FCT, Portugal) for the financial support provided to CQVR through UIDB/00616/2020. Ana R. Teixeira also thanks the FCT for the financial support provided through the doctoral scholarship $\mathrm{UI} / \mathrm{BD} / 150847 / 2020$.

Institutional Review Board Statement: Not applicable.

Informed Consent Statement: Not applicable.

Data Availability Statement: Not applicable.

Conflicts of Interest: The authors declare no conflict of interest.

\title{
References
}

1. OIV. State of the World Vitiviniculture Sector in 2020-2021; OIV: Paris, France, 2020; pp. 1-19.

2. Ferreira, R.; Gomes, J.; Martins, R.C.; Costa, R.; Quinta-Ferreira, R.M. Winery Wastewater Treatment by Integrating Fenton's Process with Biofiltration by Corbicula Fluminea. J. Chem. Technol. Biotechnol. 2018, 93, 333-339. [CrossRef]

3. Ioannou, L.A.; Fatta-Kassinos, D. Solar Photo-Fenton Oxidation against the Bioresistant Fractions of Winery Wastewater. J. Environ. Chem. Eng. 2013, 1, 703-712. [CrossRef]

4. Ioannou, L.A.; Puma, G.L.; Fatta-Kassinos, D. Treatment of Winery Wastewater by Physicochemical, Biological and Advanced Processes: A Review. J. Hazard. Mater. 2015, 286, 343-368. [CrossRef] [PubMed]

5. Mosteo, R.; Sarasa, J.; Ormad, M.P.; Ovelleiro, J.L. Sequential Solar Photo-Fenton-Biological System for the Treatment of Winery Wastewaters. J. Agric. Food Chem. 2008, 56, 7333-7338. [CrossRef] [PubMed]

6. Chatzilazarou, A.; Katsoyannos, E.; Gortzi, O.; Lalas, S.; Paraskevopoulos, Y.; Dourtoglou, E.; Tsaknis, J. Removal of Polyphenols from Wine Sludge Using Cloud Point Extraction. J. Air Waste Manag. Assoc. 2010, 60, 454-459. [CrossRef] [PubMed]

7. Mohana, S.; Acharya, B.K.; Madamwar, D. Distillery Spent Wash: Treatment Technologies and Potential Applications. J. Hazard. Mater. 2009, 163, 12-25. [CrossRef]

8. Amaral-Silva, N.; Martins, R.C.; Paiva, C.; Castro-Silva, S.; Quinta-Ferreira, R.M. A New Winery Wastewater Treatment Approach during Vintage Periods Integrating Ferric Coagulation, Fenton Reaction and Activated Sludge. J. Environ. Chem. Eng. 2016, 4, 2207-2215. [CrossRef]

9. Spennati, E.; Casazza, A.A.; Converti, A. Winery Wastewater Treatment by Microalgae to Production Purposes. Energies 2020, 13, 2490. [CrossRef]

10. Marchão, L.; Fernandes, J.R.; Sampaio, A.; Peres, J.A.; Tavares, P.B.; Lucas, M.S. Microalgae and Immobilized TiO $2 /$ UV-A LEDs as a Sustainable Alternative for Winery Wastewater Treatment. Water Res. 2021, 203, 117464. [CrossRef]

11. Jorge, N.; Teixeira, A.R.; Lucas, M.S.; Peres, J.A. Combination of adsorption in natural clays and photo-catalytic processes for winery wastewater treatment. In Advances in Geoethics and Groundwater Management: Theory and Practice for a Sustainable Development; Abrunhosa, M., Chambel, A., Peppoloni, S., Chaminé, H.I., Eds.; Springer: Cham, Switzerland, 2021; pp. 291-294, ISBN 978-3-030-59320-9.

12. Amor, C.; Rodríguez-Chueca, J.; Fernandes, J.L.; Domínguez, J.R.; Lucas, M.S.; Peres, J.A. Winery Wastewater Treatment by Sulphate Radical Based-Advanced Oxidation Processes (SR-AOP): Thermally vs UV-Assisted Persulphate Activation. Process Saf. Environ. Prot. 2019, 122, 94-101. [CrossRef]

13. Domínguez, C.M.; Quintanilla, A.; Casas, J.A.; Rodriguez, J.J. Treatment of Real Winery Wastewater by Wet Oxidation at Mild Temperature. Sep. Purif. Technol. 2014, 129, 121-128. [CrossRef]

14. Alexander, J.A.; Abbas, M.; Zaini, A.; Aliyu, E.U.; Omeiza, A.U.; Asanja, J.; Abbas, M.; Zaini, A. Surface Modification of Low-Cost Bentonite Adsorbents-A Review. Part. Sci. Technol. 2019, 37, 534-545. [CrossRef]

15. Vieira, M.G.A.; Neto, A.F.A.; Gimenes, M.L.; Silva, M.G.C. Sorption Kinetics and Equilibrium for the Removal of Nickel Ions from Aqueous Phase on Calcined Bofe Bentonite Clay. J. Hazard. Mater. 2010, 177, 362-371. [CrossRef] [PubMed]

16. Salazar, F.N.; Marangon, M.; Labbé, M.; Lira, E.; Rodríguez-Bencomo, J.J.; López, F. Comparative Study of Sodium Bentonite and Sodium-Activated Bentonite Fining during White Wine Fermentation: Its Effect on Protein Content, Protein Stability, Lees Volume, and Volatile Compounds. Eur. Food Res. Technol. 2017, 243, 2043-2054. [CrossRef]

17. Hu, P.; Long, M. Cobalt-Catalyzed Sulfate Radical-Based Advanced Oxidation: A Review on Heterogeneous Catalysts and Applications. Appl. Catal. B Environ. 2016, 181, 103-117. [CrossRef]

18. Huang, J.; Zhang, H. Mn-Based Catalysts for Sulfate Radical-Based Advanced Oxidation Processes: A Review. Environ. Int. 2019, 133, 105141. [CrossRef] 
19. Wang, J.; Wang, S. Activation of Persulfate (PS) and Peroxymonosulfate (PMS) and Application for the Degradation of Emerging Contaminants. Chem. Eng. J. 2018, 334, 1502-1517. [CrossRef]

20. Romero, A.; Santos, A.; Vicente, F.; González, C. Diuron Abatement Using Activated Persulphate: Effect of pH, Fe (II) and Oxidant Dosage. Chem. Eng. J. 2010, 162, 257-265. [CrossRef]

21. Liu, H.; Bruton, T.A.; Li, W.; Van Buren, J.; Prasse, C.; Doyle, F.M.; Sedlak, D.L. Oxidation of Benzene by Persulfate in the Presence of Fe (III)-and Mn (IV)-Containing Oxides: Stoichiometric Efficiency and Transformation Products. Environ. Sci. Technol. 2016, 50, 890-898. [CrossRef]

22. Bolobajev, J.; Trapido, M.; Goi, A. Improvement in Iron Activation Ability of Alachlor Fenton-like Oxidation by Ascorbic Acid. Chem. Eng. J. 2015, 281, 566-574. [CrossRef]

23. Govindan, K.; Raja, M.; Noel, M.; James, E.J. Degradation of Pentachlorophenol by Hydroxyl Radicals and Sulfate Radicals Using Electrochemical Activation of Peroxomonosulfate, Peroxodisulfate and Hydrogen Peroxide. J. Hazard. Mater. 2014, $272,42-51$. [CrossRef] [PubMed]

24. Giannakis, S.; Vives, F.A.G.; Grandjean, D.; Magnet, A.; De Alencastro, L.F.; Pulgarin, C. Effect of Advanced Oxidation Processes on the Micropollutants and the Effluent Organic Matter Contained in Municipal Wastewater Previously Treated by Three Different Secondary Methods. Water Res. 2015, 84, 295-306. [CrossRef]

25. Monteagudo, J.M.; Durán, A.; Latorre, J.; Expósito, A.J. Application of Activated Persulfate for Removal of Intermediates from Antipyrine Wastewater Degradation Refractory towards Hydroxyl Radical. J. Hazard. Mater. 2016, 306, 77-86. [CrossRef] [PubMed]

26. Gu, X.; Lu, S.; Li, L.; Qiu, Z.; Sui, Q.; Lin, K.; Luo, Q. Oxidation of 1, 1, 1-Trichloroethane Stimulated by Thermally Activated Persulfate. Ind. Eng. Chem. Res. 2011, 50, 11029-11036. [CrossRef]

27. Tan, C.; Gao, N.; Zhou, S.; Xiao, Y.; Zhuang, Z. Kinetic Study of Acetaminophen Degradation by UV-Based Advanced Oxidation Processes. Chem. Eng. J. 2014, 253, 229-236. [CrossRef]

28. Mahdi-ahmed, M.; Chiron, S. Ciprofloxacin Oxidation by UV-C Activated Peroxymonosulfate in Wastewater. J. Hazard. Mater. 2014, 265, 41-46. [CrossRef]

29. Karthikeyan, S.; Boopathy, R.; Sekaran, G. In Situ Generation of Hydroxyl Radical by Cobalt Oxide Supported Porous Carbon Enhance Removal of Refractory Organics in Tannery Dyeing Wastewater. J. Colloid Interface Sci. 2015, 448, 163-174. [CrossRef] [PubMed]

30. Ghanbari, F.; Moradi, M.; Gohari, F. Degradation of 2,4,6-Trichlorophenol in Aqueous Solutions Using Peroxymonosulfate/Activated Carbon/UV Process via Sulfate and Hydroxyl Radicals. J. Water Process Eng. 2016, 9, 22-28. [CrossRef]

31. Devi, P.; Das, U.; Dalai, A.K. In-Situ Chemical Oxidation: Principle and Applications of Peroxide and Persulfate Treatments in Wastewater Systems. Sci. Total Environ. 2016, 571, 643-657. [CrossRef]

32. Cui, H.; Gu, X.; Lu, S.; Fu, X.; Zhang, X.; Fu, G.Y.; Qiu, Z.; Sui, Q. Degradation of Ethylbenzene in Aqueous Solution by Sodium Percarbonate Activated with EDDS-Fe (III) Complex. Chem. Eng. J. 2017, 309, 80-88. [CrossRef]

33. APHA; AWWA; WEF. Standard Methods for the Examination of Water and Wastewater, 20th ed.; American Public Health Association: Washington, DC, USA; American Water Works Association: Denver, CO, USA; Water Environment Federation: Alexandria, VR, USA, 1999.

34. Singleton, V.L.; Rossi, J.A. Colorimetry of Total Phenolics with Phosphomolybdic-Phosphotungstic Acid Reagents. Am. J. Enol. Vitic. 1965, 16, 144-158.

35. OECD. OECD Guidelines for the Testing of Chemicals: Terrestrial Plant Test; OECD: Paris, France, 2004; Volume 208.

36. Varnero, M.T.; Rojas, C.; Orellana, R. Índices de Fitotoxicidad en Residuos Orgánicos Durante el Compostaje. Rev. Cienc. Suelo Nutr. Veg. 2007, 7, 28-37. [CrossRef]

37. Tiquia, S.M.; Tam, N.F.Y. Elimination of Phytotoxicity during Co-Composting of Spent Pig-Manure Sawdust Litter and Pig Sludge. Bioresour. Technol. 1998, 65, 43-49. [CrossRef]

38. OIV. Compendium of International Methods of Wine and Must Analysis-Volume I, 2017th ed.; OIV: Paris, France, 2017; ISBN 979-10-91799-64-5.

39. Curvelo-Garcia, A. Controlo de qualidade dos vinhos. In Química Enológica e Métodos Analíticos. Avanços Recentes no Controlo da Qualidade de Vinhos e de Outros Produtos Vitivinícolas; Curvelo-Garcia, A.S., e Barros, P., Eds.; Engebook/Publindustria, Edições Técnicas, Lda: Lisboa, Portugal, 1988; ISBN 978-989-723-118-6.

40. Kramling, T.E.; Singleton, V.L. An Estimate of the Nonflavonoid Phenols in Wines. Am. J. Enol. Vitic. 1969, $20,86-92$.

41. Ribéreau-Gayon, P.; Glories, Y.; Maujean, A.; Dubourdieu, D. Handbook of Enology-Volume 2. The Chemistry of Wine Stabilization and Treatments, 2nd ed.; John Wiley \& Sons, Inc: Hoboken, NJ, USA, 2021; Volume 2, ISBN 9780470010396.

42. Somers, T.C.; Evans, M.E. Spectral Evaluation of Young Red Wines: Anthocyanin Equilibria, Total Phenolics, Free and Molecular $\mathrm{SO}_{2}$, "Chemical Age". J. Sci. Food Agric. 1977, 28, 279-287. [CrossRef]

43. Ribéreau-Gayon, P.; Stonestreet, E. Dosage des Tanins du Vin Rouge et Détermination de Leur Structure. Chim. Anal. 1966, $48,188$.

44. Spagna, G.; Pifferi, G.; Rangoni, C.; Mattivi, F.; Nicolinib, G.; Palmonari, R. The Stabilization of White Wines by Adsorption of Phenolic Compounds on Chitin and Chitosan. Food Res. Int. 1996, 29, 241-248. [CrossRef]

45. Schanda, J. Colorimetry: Understanding the CIE System; John Wiley \& Sons, Inc: Hoboken, NJ, USA, 2007; ISBN 978-0-470-04904-4.

46. Jorge, N.; Teixeira, A.R.; Matos, C.C.; Lucas, M.S.; Peres, J.A. Combination of Coagulation-Flocculation-Decantation and Ozonation Processes for Winery Wastewater Treatment. Int. J. Environ. Res. Public Health 2021, 18, 8882. [CrossRef]

47. Hojiyev, R.; Ulcay, Y.; Çelik, M.S. Development of a Clay-Polymer Compatibility Approach for Nanocomposite Applications. Appl. Clay Sci. 2017, 146, 548-556. [CrossRef] 
48. Schuttlefield, J.D.; Cox, D.; Grassian, V.H. An Investigation of Water Uptake on Clays Minerals Using ATR-FTIR Spectroscopy Coupled with Quartz Crystal Microbalance Measurements. J. Geophys. Res. Atmos. 2007, 112, 1-14. [CrossRef]

49. Sevim, A.M.; Hojiyev, R.; Gül, A.; Celik, M.S. Preparation of Novel Heterogeneous Catalysts by Adsorption of a Cationic Tetrapyrrole on to Bentonite: Equilibrium, Kinetics, and Thermodynamics. Mon. Für Chem.-Chem. Mon. 2012, 143, 385-400. [CrossRef]

50. Żymankowska-kumon, S.; Holtzer, M.; Olejnik, E.; Bobrowski, A. Influence of the Changes of the Structure of Foundry Bentonites on Their Binding Properties. Mater. Sci. 2012, 18, 57-61. [CrossRef]

51. Guimarães, V.; Teixeira, A.R.; Lucas, M.S.; Silva, A.M.T.; Peres, J.A. Pillared Interlayered Natural Clays as Heterogeneous Photocatalysts for $\mathrm{H}_{2} \mathrm{O}_{2}$-Assisted Treatment of a Winery Wastewater. Sep. Purif. Technol. 2019, 228, 115768. [CrossRef]

52. Barros, W.R.P.; Steter, J.R.; Lanza, M.R.V.; Tavares, A.C. Catalytic Activity of $\mathrm{Fe}_{3-\mathrm{x}} \mathrm{Cu}_{\mathrm{x}} \mathrm{O}_{4}(0 \leq \mathrm{x} \leq 0.25)$ Nanoparticles for the Degradation of Amaranth Food Dye by Heterogeneous Electro-Fenton Process. Appl. Catal. B Environ. 2016, 180, 434-441. [CrossRef]

53. Guimarães, V.; Lucas, M.S.; Peres, J.A. Combination of Adsorption and Heterogeneous Photo-Fenton Processes for the Treatment of Winery Wastewater. Environ. Sci. Pollut. Res. 2019, 26, 31000-31013. [CrossRef]

54. Putra, E.K.; Pranowo, R.; Sunarsob, J.; Indraswati, N.; Ismadji, S. Performance of Activated Carbon and Bentonite for Adsorption of Amoxicillin from Wastewater: Mechanisms, Isotherms and Kinetics. Water Res. 2009, 43, 2419-2430. [CrossRef] [PubMed]

55. Bergaya, F.; Theng, B.K.G.; Lagaly, G. Handbook of Clay Science, Volume 1; Elsevier: Amsterdam, The Netherlands, 2006 ; ISBN 9780080457635.

56. Guimarães, V.; Rodríguez-Castellón, E.; Algarra, M.; Rocha, F.; Bobos, I. Influence of pH, Layer Charge Location and Crystal Thickness Distribution on U(VI) Sorption onto Heterogeneous Dioctahedral Smectite. J. Hazard. Mater. 2016, 317, $246-258$. [CrossRef] [PubMed]

57. Benna, M.; Magnin, A.; Bergaya, F. Effect of pH on Rheological Properties of Purified Sodium Bentonite Suspensions. J. Colloid Interface Sci. 1999, 218, 442-455. [CrossRef] [PubMed]

58. Sharma, P.; Borah, D.J.; Das, P.; Das, M.R. Cationic and Anionic Dye Removal from Aqueous Solution Using Montmorillonite Clay: Evaluation of Adsorption Parameters and Mechanism. Desalin. Water Treat. 2016, 57, 8372-8388. [CrossRef]

59. Zonfrilli, F.; Germanà, S.; Guida, V.; Italia, G. Thermal Stability of Dry Detergent Formulation Containing Sodium Percarbonate. Chem. Eng. Trans. 2009, 17, 705-710. [CrossRef]

60. Rodríguez-Chueca, J.; Amor, C.; Mota, J.; Lucas, M.S.; Peres, J.A. Oxidation of Winery Wastewater by Sulphate Radicals: Catalytic and Solar Photocatalytic Activations. Environ. Sci. Pollut. Res. 2017, 24, 22414-22426. [CrossRef]

61. Rodríguez-Chueca, J.; Amor, C.; Silva, T.; Dionysiou, D.D.; Li, G.; Lucas, M.S.; Peres, J.A. Treatment of Winery Wastewater by Sulphate Radicals: $\mathrm{HSO}_{5}{ }^{-}$/Transition Metal/UV-A LEDs. Chem. Eng. J. 2017, 310, 473-483. [CrossRef]

62. Deng, Y.; Ezyske, C.M. Sulfate Radical-Advanced Oxidation Process (SR-AOP) for Simultaneous Removal of Refractory Organic Contaminants and Ammonia in Landfill Leachate. Water Res. 2011, 5, 6189-6194. [CrossRef]

63. Hilles, A.H.; Abu, S.S.; Hussein, R.A.; El-Sebaie, O.D.; Arafa, A.I. Performance of Combined Sodium Persulfate/ $\mathrm{H}_{2} \mathrm{O}_{2}$ Based Advanced Oxidation Process in Stabilized Land Fi Ll Leachate Treatment. J. Environ. Manag. 2016, 166, 493-498. [CrossRef] [PubMed]

64. Huie, R.E.; Clifton, C.L.; Neta, P. Electron Transfer Reaction Rates and Equilibria of the Carbonate and Sulfate Radical Anions. Int. J. Radiat. Appl. Instrum. Part C Radiat. Phys. Chem. 1991, 38, 477-481. [CrossRef]

65. Han, D.; Wan, J.; Ma, Y.; Wang, Y.; Huang, M.; Chen, Y.; Li, D.; Guan, Z.; Li, Y. Enhanced Decolorization of Orange G in a Fe (II)-EDDS Activated Persulfate Process by Accelerating the Regeneration of Ferrous Iron with Hydroxylamine. Chem. Eng. J. 2014, 256, 316-323. [CrossRef]

66. Hilles, A.H.; Abu, S.S.; Hussein, R.A.; Arafa, A.I.; El-sebaie, O.D. Effect of Persulfate and Persulfate/H2O2 on Biodegradability of an Anaerobic Stabilized Landfill Leachate. Waste Manag. 2015, 44, 172-177. [CrossRef] [PubMed]

67. Candia-Onfray, C.; Espinoza, N.; da Silva, E.B.S.; Toledo-Neira, C.; Espinoza, L.C.; Santander, R.; García, V.; Salazar, R. Treatment of Winery Wastewater by Anodic Oxidation Using BDD Electrode. Chemosphere 2018, 206, 709-717. [CrossRef] [PubMed]

68. Furman, O.S.; Teel, A.L.; Ahmad, M.; Merker, M.C.; Watts, R.J. Effect of Basicity on Persulfate Reactivity. J. Environ. Eng. 2011, 137, 241-247. [CrossRef]

69. Yang, Y.; Pignatello, J.J.; Ma, J.; Mitch, W.A. Comparison of Halide Impacts on the Efficiency of Contaminant Degradation by Sulfate and Hydroxyl Radical-Based Advanced Oxidation Processes (AOPs). Environ. Sci. Technol. 2014, 48, 2344-2351. [CrossRef] [PubMed]

70. Zhao, D.; Liao, X.; Yan, X.; Huling, S.G.; Chai, T.; Tao, H. Effect and Mechanism of Persulfate Activated by Different Methods for PAHs Removal in Soil. J. Hazard. Mater. 2013, 254-255, 228-235. [CrossRef]

71. Zrinyi, N.; Pham, A.L. Oxidation of Benzoic Acid by Heat-Activated Persulfate: Effect of Temperature on Transformation Pathway and Product Distribution. Water Res. 2017, 120, 43-51. [CrossRef] [PubMed]

72. Jaafarzadeh, N.; Ghanbari, F.; Alvandi, M. Integration of Coagulation and Electro-Activated $\mathrm{HSO}_{5}{ }^{-}$to Treat Pulp and Paper Wastewater. Sustain. Environ. Res. 2017, 27, 223-229. [CrossRef]

73. Amor, C.; De Torres-Socías, E.; Peres, J.A.; Maldonado, M.I.; Oller, I.; Malato, S.; Lucas, M.S. Mature Landfill Leachate Treatment by Coagulation/Flocculation Combined with Fenton and Solar Photo-Fenton Processes. J. Hazard. Mater. 2015, 286, 261-268. [CrossRef] [PubMed]

74. Casa, R.; Annibale, A.D.Õ.; Pieruccetti, F.; Stazi, S.R.; Sermanni, G.G.; Cascio, B. Lo Reduction of the Phenolic Components in Olive-Mill Wastewater by an Enzymatic Treatment and Its Impact on Durum Wheat (Triticum Durum Desf.) Germinability. Chemosphere 2003, 50, 959-966. [CrossRef]

75. Mosse, K.P.M.; Patti, A.F.; Christen, E.W.; Cavagnaro, T.R. Winery Wastewater Inhibits Seed Germination and Vegetative Growth of Common Crop Species. J. Hazard. Mater. 2010, 180, 63-70. [CrossRef] [PubMed] 
76. Rizzo, L.; Fiorentino, A.; Grassi, M.; Attanasio, D.; Guida, M. Advanced Treatment of Urban Wastewater by Sand Filtration and Graphene Adsorption for Wastewater Reuse: Effect on a Mixture of Pharmaceuticals and Toxicity. J. Environ. Chem. Eng. 2015, 3, 122-128. [CrossRef]

77. Lucas, M.S.; Peres, J.A.; Li, G. Treatment of Winery Wastewater by Ozone-Based Advanced Oxidation Processes $\left(\mathrm{O}_{3}, \mathrm{O}_{3} / \mathrm{UV}\right.$ and $\mathrm{O}_{3} / \mathrm{UV} / \mathrm{H}_{2} \mathrm{O}_{2}$ ) in a Pilot-Scale Bubble Column Reactor and Process Economics. Sep. Purif. Technol. 2010, 72, 235-241. [CrossRef]

78. Li, L.; Sun, B. Grape and Wine Polymeric Polyphenols: Their Importance in Enology. Crit. Rev. Food Sci. Nutr. 2019, 59, 563-579. [CrossRef] [PubMed]

79. Cheynier, V.; Dueñas-Paton, M.; Salas, E.; Maury, C.; Souquet, J.; Sarni-manchado, P.; Fulcrand, H. Structure and Properties of Wine Pigments and Tannins. Am. J. Enol. Vitic. 2006, 57, 298-305. [CrossRef] 